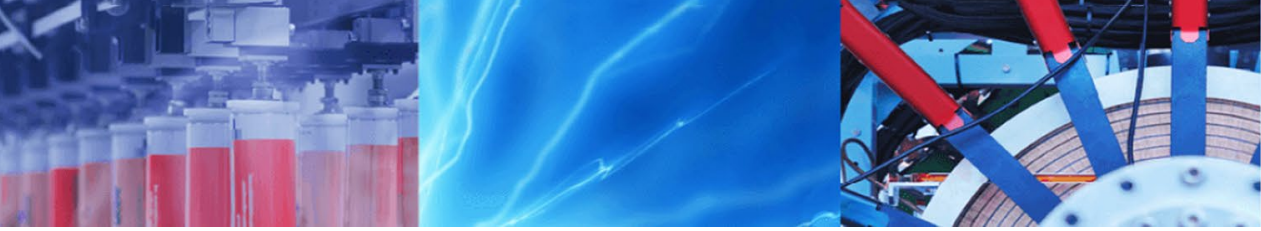

Research Article

\title{
Evaluation of seasonal and temporal variations of groundwater quality around Jawaharnagar municipal solid waste dumpsite of Hyderabad city, India
}

\author{
B. Soujanya Kamble ${ }^{1} \cdot$ Praveen Raj Saxena ${ }^{2} \cdot$ Rama Mohan Kurakalva $^{3} \cdot \mathrm{K}$. Shankar $^{2}$ (D)
}

Received: 19 June 2019 / Accepted: 5 February 2020 / Published online: 27 February 2020

(c) Springer Nature Switzerland AG 2020

\begin{abstract}
The present study aimed to assess the impact of municipal solid waste dumpsite on groundwater bodies at Hyderabad, India. Leachate and groundwater samples collected through pre- and post-monsoon analyzed the physicochemical, microbiological, biological and heavy metals. The analytical data were compared with Bureau of Indian Standards (BIS) drinking water quality standards. Water quality index (WQI), heavy metal pollution indices like heavy metal evaluation index (HEI) and degree of contamination (Cd) are calculated for groundwater samples. High total dissolve solids values in leachates revealed that they were highly contaminated with organic and inorganic salts. Biological oxygen demand values indicated that dumpsite was "old and stabilized" with decreasing biodegradability from time to time. According to WQI, about $75 \%$ of the water samples identified as "Poor" category that is not suitable for neither drinking nor domestic purposes as per BIS standards. Similarly, $\mathrm{HEI}$ and $\mathrm{Cd}$ results indicated that majority of the samples are labeled with low-metal pollution status. Spatial patterns obtained through geographic information systems using inverse distance weighted interpolation technique revealed that the concentrations of various parameters are high due to increased degradation of solid wastes during rainfall, especially during the post-monsoon. The study suggested that leachates have treated prior to disposal on land, and continuous monitoring of groundwater wells is required to minimize the pollution and potential health hazards.
\end{abstract}

Keywords Leachate - Municipal dumpsite · GIS · Groundwater · Heavy metal evaluation index (HEI) - Water quality index (WQI)

\section{Introduction}

India is the seventh largest country by area, the second most populous country with over 1.2 billion people and one of the mega diversity regions in the world. However, when it comes to MSW management, little is the way it is meant to be. With rapid industrialization and population growth, MSW has increased tremendously due to increased lifestyles and social status of the people. According to Ministry of Urban Affairs, Govt. of India estimates, India is generating approximately 100,000 metric tons of solid waste everyday of which $90 \%$ is disposed in the open place [1]. In spite of specifications of municipal solid wastes (management and handling rules) developed by MoEF \& CC [2] for collection, segregation, storage, transportation, processing and disposal, lack of implementation

K. Shankar, geoshankar1984@gmail.com; B. Soujanya Kamble, bsk.029@gmail.com; Praveen Raj Saxena, saxenapraveenraj@ gmail.com; Rama Mohan Kurakalva, krenviron@ngri.res.in | 'Department of Environmental Science, CVR College of Engineering, Mangalpalli, Ibrahimpatnam, India. ${ }^{2}$ Department of Applied Geology, School of Applied Natural Sciences, Adama Science and Technology University, Adama, Ethiopia. ${ }^{3}$ Hydrogeochemistry Group, CSIR-National Geophysical Research Institute (NGRI), Uppal Road, Hyderabad 500007, India. 
is the main cause for the widespread of open waste disposal. Unconditional open dumping of the garbage in the absence of protective liners beneath causes leachate percolation into the aquifer system. It is a thick toxic soup which flows out of the decomposing solid wastes carrying harmful constituents like organic matter, heavy metals and xenobiotic organic compounds as a result of precipitation. Further, it seeps into the very next recipient soil and ultimately reaches the groundwater table disrupting the natural phenomena of hydrological cycle. Groundwater contamination due to MSW leachate poses a serious threat to the biotic communities as it is an important resource for drinking and agriculture purposes. Quality assessment and regular monitoring of groundwater wells around the dumpsites are also the need of an hour. Several scientific studies [3-13] are being carried out worldwide on MSW leachate pollution impact on water bodies. Spatial variation of groundwater quality depends on the geological formation through which it flows and on anthropogenic activities in the groundwater [14-31].

WQI is the superior environmental criterion and one of the most effective tools, which ultimately describes the water quality status for drinking purpose. The general WQI was developed [32] and improved by Deininger for the Scottish Development Department in [33]. WQI provides a single value that expresses overall water quality at a certain location. It converts the complex water quality data into information that is understandable and useable by the public and helps in developing environmental management strategies to control the groundwater pollution. In addition, water quality index (WQI) has been widely used to indicate a water quality class for drinking use [34]. Details on computation of WQI using relative weight and quality rating scale are presented in [20,34-45].

Heavy metal pollution indices like heavy metal evaluation index (HEI) and degree of contamination (Cd) also hugely contribute in assessing the pollution status of the groundwater resources. Various researchers have successfully used $\mathrm{HEl}$ and $\mathrm{Cd}$ for interpretation of heavy metal pollution [46-62] and several others.

Geographic information system (GIS) combined with IDW interpolation technique is a powerful package in assessing and regular monitoring of the groundwater quality. It is less time-consuming and cost-effective process which transforms huge sets of data collection into spatial projections to observe the patterns and connections of pollutants. It also helps in identifying probable sources and origin of the contaminants. GIS-based study is the best idea to observe the evolution tendency of the water quality which keeps changing from time to time. This modern approach tremendously helps in precise monitoring and quick decision making process for environmental managers and decision makers.
In view of the above, the present investigations were undertaken at Jawaharnagar dumpsite with the following objectives (1) to assess the impact of leachates on groundwater quality (2) to study the seasonal variation of groundwater quality in two hydrological cycles and (3) to assess the extent of groundwater contamination using WQI and other heavy metal pollution indices with the aid of GIS.

\section{Study area}

Municipal solid waste dumpsite is situated in Jawaharnagar Village near Hyderabad city. It is just outside the limits of Greater Hyderabad Municipal Corporation (GHMC) and inside the HMDA (New limits of Hyderabad). The site is $35 \mathrm{~km}$ from Hyderabad city and $105 \mathrm{~km}$ away from the state highway connecting Hyderabad and Nagpur in west direction from boundary of project site. It is an open dumpsite which was established in the year 2002. The total area of Jawaharnagar village dumpsite is 350 acres from which the area occupied by the waste at present is 182 acres. It is located between $70^{\circ} 30^{\prime} 01^{\prime \prime} \mathrm{N}$ to $17^{\circ} 32^{\prime} 03^{\prime \prime}$ N latitude and $78^{\circ} 34^{\prime} 13^{\prime \prime} \mathrm{E}$ to $78^{\circ} 37^{\prime} 47^{\prime \prime} \mathrm{E}$ longitude. The location map of the study area was prepared using Arc GIS 10.1 software developed by ESRI (Fig. 1).

Hyderabad is the capital city of Telangana state and is the sixth largest city in India. Currently, 5000 metric tons (MT) of municipal solid waste is generated in the city. This waste is collected by the municipal authorities with the help of tricycle carts and dumped into the three major collection points which are located in Yousufguda, Imlibun and Lower Tank bund. Eventually, waste collected from all the three collection points in the city are transported through trucks and dumped into the municipal dumpsite of Jawaharnagar without proper segregation and recycling process. The percentage composition of the municipal solid waste generated in Hyderabad city (Fig. 2) was reported elsewhere [63].

At the vicinity of the MSW dumpsite, it is observed that groundwater table is at $120 \mathrm{~cm}$ below ground level. The annual mean temperature is $26^{\circ} \mathrm{C}$. Summers are hot with maximum temperatures of $40^{\circ} \mathrm{C}$. Winter has temperatures varying from 14.7 to $28.6^{\circ} \mathrm{C}$. Heavy rain from the southwest monsoon falls between June and September, with annual rainfall of $812.5 \mathrm{~mm}$.

\section{Methodology}

\subsection{Sampling of leachate and groundwater}

To examine the effect of leachate pollution on groundwater, leachate samples at two stations and twenty-three (23) 


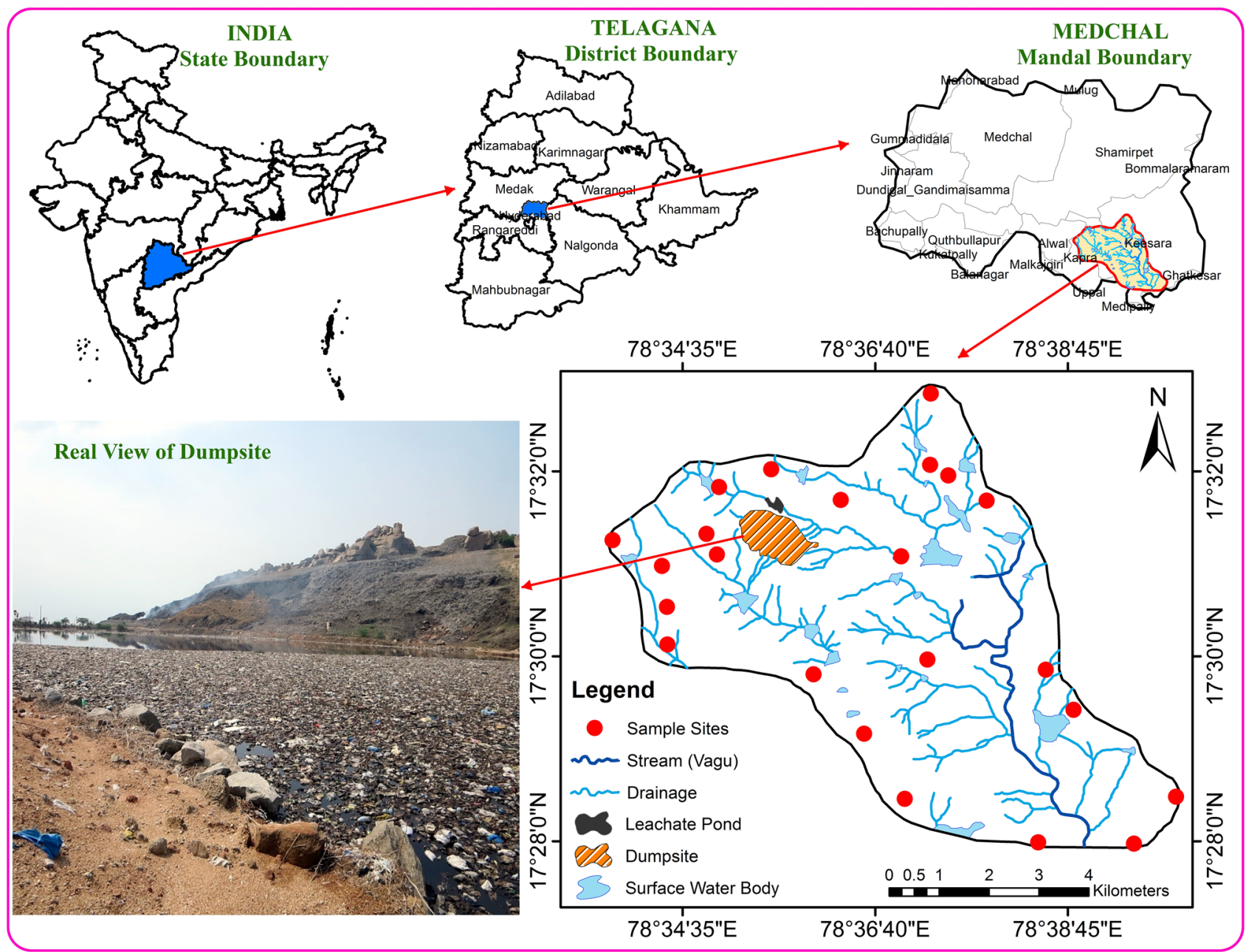

Fig. 1 Location map of the study area (i.e., Jawaharnagar dumpsite)

Fig. 2 Percentage composition of municipal solid waste in Hyderabad. Source: Raj et al. [63]

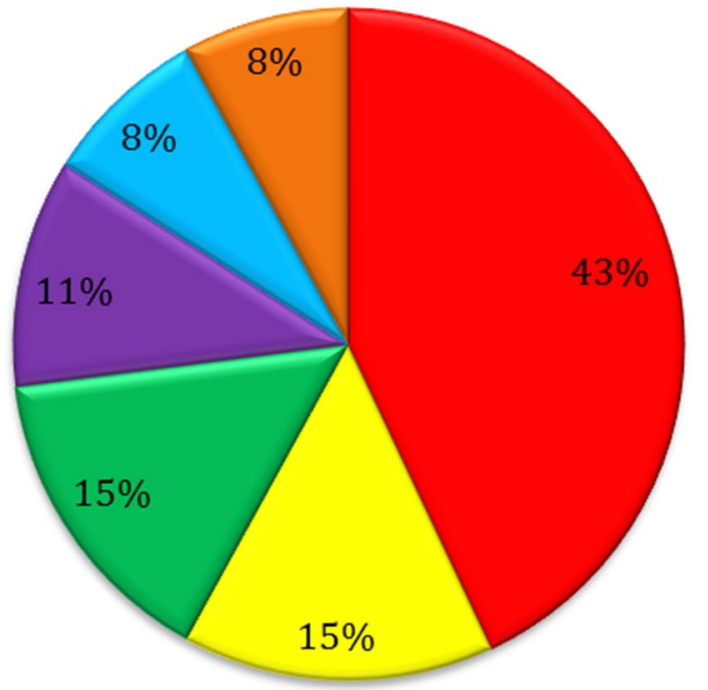

Domestic Household

$\square$ Hotels and Restaurants

口 Construction and Demolition

Q Markets

$\square$ Commercial establishments

$\square$ Street sweeping groundwater samples were collected around the dumpsite during pre- and post-monsoon in 2014 and 2015. Simple random sampling technique was employed covering an area of approximately $49 \mathrm{sq} . \mathrm{km}$ around the dumpsite to 
Table 1 Geographic coordinates of groundwater and leachates of the study area

\begin{tabular}{|c|c|c|c|c|c|}
\hline S. no. & $\begin{array}{l}\text { Sample site hamlet/vil- } \\
\text { lage name }\end{array}$ & Sample ID & Latitude & Longitude & $\begin{array}{l}\text { Sampling distance } \\
\text { from dumpsite } \\
(\mathrm{km})\end{array}$ \\
\hline 1 & Dammaiguda & GW1 & 17.29.34.5 & 78.33.0.705 & 3 \\
\hline 2 & Yadgarpally & GW2 & 17.31.56.411 & 78.37.21.664 & 4 \\
\hline 3 & Godumkunta & GW3 & 17.29.28.432 & 78.38 .43 .162 & 5.7 \\
\hline 4 & Kundanpally & GW4 & 17.29.55.108 & 78.38 .25 .447 & 4.4 \\
\hline 5 & Karimguda & GW5 & 17.28 .34 .378 & 78.39 .50 .537 & 8.7 \\
\hline 6 & Malkaram & GW6 & 17.31.47.652 & 78.34 .55 .495 & 1.2 \\
\hline 7 & Y.S.R nagar & GW7 & 17.31.4.573 & 78.34 .50 .461 & 1.7 \\
\hline 8 & Indiramma Jinnaram & GW8 & 17.31.5.509 & 78.32 .56 .063 & 2.5 \\
\hline 9 & Cheriyal & GW9 & 17.31 .40 .039 & 78.37.46.538 & 4.2 \\
\hline 10 & Haridaspally & GW10 & 17.31.38.914 & 78.36.12.954 & 1.2 \\
\hline 11 & Ahmedguda & GW11 & 17.29 .59 .023 & 78.37.8.062 & 4.2 \\
\hline 12 & Nagaram & GW12 & 17.29.11.757 & 78.36.27.773 & 5 \\
\hline 13 & Gabbilalpet & GW13 & 17.31.17.408 & 78.34.44.687 & 1.4 \\
\hline 14 & Yadgarpally 2 & GW14 & 17.32 .1 .653 & 78.37.10.386 & 4 \\
\hline 15 & Jawaharnagar & GW15 & 17.31.59.331 & 78.35 .27 .287 & 840 (in m) \\
\hline 16 & Karimguda 2 & GW16 & 17.28.9.435 & 78.39.32.925 & 8.7 \\
\hline 17 & Rampally & GW17 & 17.28 .8 .413 & 78.38.6.652 & 8.5 \\
\hline 18 & Charkpally & GW18 & 17.28.30.689 & 78.36 .55 .765 & 4.1 \\
\hline 19 & Wampugudem & GW19 & 17.30.6.671 & 78.34.20.407 & 5.3 \\
\hline 20 & Ambedkarnagar & GW20 & 17.30 .31 .96 & 78.34 .21 .753 & 6.2 \\
\hline 21 & Chennapur & GW21 & 17.30.56.098 & 78.34.16.948 & 3.1 \\
\hline 22 & Balajinagar & GW22 & 17.31 .13 .434 & 78.33 .43 .652 & 4.4 \\
\hline 23 & Timmaipally & GW23 & 17.32 .50 .585 & 78.37.10.307 & 6.1 \\
\hline 24 & Leachate 1 & $L 1$ & 17.31.59.330 & 78.35 .27 .280 & $120(\mathrm{~m})$ \\
\hline 25 & Leachate 2 & $L 2$ & 17.31.59.329 & 78.35.27.279 & $121(\mathrm{~m})$ \\
\hline
\end{tabular}

observe the variations due to leachate pollution. The sampling locations were recorded using GPS (Table 1). All the samples were collected in 1-L pre-cleaned high-density polyethylene bottles (HDPE), transferred to the laboratory and were stored at $4{ }^{\circ} \mathrm{C}$ and analyzed within 2 days of sampling following APHA [64] methods. All the samples were analyzed for physicochemical parameters, viz. $\mathrm{pH}, \mathrm{EC}$, TDS, TA, $\mathrm{TH}, \mathrm{Ca}^{2+}, \mathrm{Mg}^{+2}, \mathrm{Na}^{+}, \mathrm{K}^{+}, \mathrm{CO}_{3}^{-2}, \mathrm{HCO}_{3}{ }^{-}, \mathrm{NO}_{3}{ }^{-}, \mathrm{SO}_{4}^{-2}$, $\mathrm{Cl}^{-}$and $\mathrm{F}^{-}$and heavy metals, viz. cadmium (Cd), copper $(\mathrm{Cu})$, lead (Pb), arsenic (As), chromium (Cr), iron (Fe), nickel (Ni) manganese (Mn) and zinc ( $\mathrm{Zn})$.

The $\mathrm{pH}$ and $\mathrm{EC}$ were measured in the field, immediately after the sampling using digital $\mathrm{pH}$ and conductivity meter (HANNA Inst). TDS was calculated using EC value using an empirical equation. $\mathrm{TA}, \mathrm{TH}, \mathrm{Ca}^{2+}, \mathrm{Mg}^{2+}$ and $\mathrm{Cl}^{-}$were estimated by titrimetry using standardized EDTA solution. Carbonates $\left(\mathrm{CO}_{3}{ }^{2-}\right)$ and bicarbonates $\left(\mathrm{HCO}_{3}{ }^{-}\right)$were determined by titration with $\mathrm{H}_{2} \mathrm{SO}_{4}$. Sodium $\left(\mathrm{Na}^{+}\right)$and potassium $\left(\mathrm{K}^{+}\right)$were determined by flame photometry. Nitrates and fluoride determination was carried out using ionselective electrodes (Orion). Sulfate $\left(\mathrm{SO}_{4}^{-2}\right)$ was measured by spectrophotometer (Spectronic 21). Heavy metals were analyzed using inductively coupled plasma optical emission spectrometry (ICP-OES, Perkin Elmer Optima 4300DV).

\subsection{Water quality index (WQI)}

In this study, for the calculation of water quality index (WQI), 11 parameters, namely $\mathrm{pH}$, electrical conductivity, total dissolved solids, total hardness, calcium, magnesium, sodium, potassium, sulfates, nitrates and chlorides were chosen. Three major steps were carried out for computing WQI for groundwater samples as follows:

(1) Each of the chemical parameters were assigned a weighting factor $\left(w_{i}\right)$ based on its importance and potential impact on overall water quality for drinking purpose. Highest weighting factor $\left(w_{i}=5\right)$ was assigned to the parameters (TDS, $\mathrm{NO}_{3}{ }^{-}$and $\mathrm{Cl}^{-}$) which are known sources of dumpsite leachate contamination in groundwater, and a minimum weighting factor $\left(w_{i}=2\right)$ was assigned to the parameters $\left(\mathrm{Ca}^{2+}\right.$, $\mathrm{Mg}^{2+}$ and $\mathrm{K}^{+}$) which have no significant effects on the water quality. 
Table 2 Relative weights of various parameters to calculate water quality index (WQI)

\begin{tabular}{llll}
\hline $\begin{array}{l}\text { Water quality } \\
\text { parameters }\end{array}$ & $\begin{array}{l}\text { BIS desirable } \\
\text { limits }(1998)^{\mathrm{a}}\end{array}$ & $\begin{array}{l}\text { Weighting fac- } \\
\text { tor }\left(w_{i}\right)\end{array}$ & $\begin{array}{l}\text { Relative } \\
\text { weight } \\
\left(W_{i}\right)\end{array}$ \\
\hline $\mathrm{pH}$ & 8.5 & 3 & 0.0769 \\
$\mathrm{EC}$ & 200 & 3 & 0.0769 \\
$\mathrm{TDS}$ & 1000 & 5 & 0.1282 \\
$\mathrm{TH}$ & 300 & 3 & 0.0769 \\
$\mathrm{Ca}^{2+}$ & 75 & 3 & 0.0769 \\
$\mathrm{Mg}^{2+}$ & 30 & 3 & 0.0769 \\
$\mathrm{Na}^{+}$ & 100 & 3 & 0.0769 \\
$\mathrm{~K}^{+}$ & 10 & 3 & 0.0769 \\
$\mathrm{SO}_{4}{ }^{2-}$ & 200 & 3 & 0.0769 \\
$\mathrm{NO}_{3}{ }^{-}$ & 45 & 5 & 0.1282 \\
$\mathrm{Cl}^{-}$ & 250 & 5 & 0.1282 \\
& & $\Sigma W_{i}=39$ & $\Sigma W_{i}=1$ \\
\hline
\end{tabular}

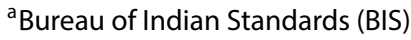

(2) The relative weight $\left(W_{i}\right)$ was calculated using following Eq. 1 (Table 2).

$W_{i}=\frac{w_{i}}{\sum_{n=1}^{n} w_{i}}$

where $W_{i}=$ relative weight, $w_{i}=$ weighting factor of each parameter and $n$ is no. of parameters.

(3) A quality rating scale $\left(q_{j}\right)$ for each chemical parameter was calculated by dividing the analytical value of each groundwater sample parameter $\left(C_{i}\right)$ with its respective [65] drinking water quality standard $\left(S_{i}\right)$. The value obtained was further multiplied with 100 using following equation

$q_{i}=\left(\frac{C_{i}}{S_{i}}\right) 100$

(4) Further, sub-index $\left(\mathrm{SI}_{i}\right)$ for each chemical parameter was calculated by substituting the obtained values of relative weight $\left(W_{i}\right)$ and quality rating scale $\left(q_{j}\right)$ of each parameter in the following equation

$\mathrm{SI}=W_{i} q_{i}$

(5) Finally, WQI was calculated by the summation of the sub-index values of all the chemical parameters using following equation

$\mathrm{WQI}=\sum_{i=1}^{n} \mathrm{SI}_{i}$

where $n=$ no. of parameters.

\subsection{Heavy metal evaluation index (HEI)}

The HEl method estimates an overall water quality status with respect to heavy metals. The HEl is computed using the following equation:

$\mathrm{HEI}=\sum_{i=1}^{n} \mathrm{Hc}_{i} / \mathrm{Hmac}_{i}$

where $\mathrm{Hc}$ is the monitored value of the $i$ th parameter and $\mathrm{Hmac}$ is the maximum admissible concentration (MAC) of ith parameter.

\subsection{Degree of contamination (Cd)}

This method is used to evaluate the water quality by calculating the degree of contamination (Cd), and it was developed by [66]. The $\mathrm{Cd}$ is calculated by summation of the contamination factors (Cfi) of individual parameters that exceed their upper permissible value for every water sample. The parameters considered include $\mathrm{As}, \mathrm{Cd}, \mathrm{Fe}, \mathrm{Cu}$, $\mathrm{Mn}, \mathrm{Zn}$. Thus, $\mathrm{Cd}$ summarized the combined effect of these heavy metal parameters in groundwater which are harmful for human consumption. The $\mathrm{Cd}$ is computed from the following equations:

$C_{d}=\sum_{i=1}^{n} C_{f i}$

$C_{f i}=\frac{\mathrm{CA}_{i}}{\mathrm{CN}_{i}}-1$

where $\mathrm{C}_{f i} \mathrm{CA}_{i}, \mathrm{CN}_{i}$ represent the contamination factor, analytical value and upper permissible concentration of the $i$ th component. The $\mathrm{CN}_{i}$ values were taken as maximum admissible concentration (MAC) value.

\subsection{Inverse distance weighted (IDW) interpolation concept}

Geostatistical analyst extension of ArcMap presents two groups of interpolation techniques such as deterministic and geostatistical. IDW is a deterministic method which predicts a value for any unmeasured location using the measured values surrounding the prediction location. The basic concept behind this prediction is that things that are closer to one another are alike than the things that are farther apart. More weights are given to the points closer to prediction location than the farther ones. Hence, it is named as inverse distance weighted.

$W \infty 1 / d^{p}$

$p$ is the optimal power which is determined by root-meansquare prediction error (RMSPE). RMSPE is determined 
using cross-validation. In cross-validation, the point which is measured is removed and compared to the value predicted for that location. This process continues for all the points present in a given space. This helps in quantifying the prediction error. Various powers are tried by geostatistical extension for IDW interpolation and plotted against RMSPE. The power $p=2$ is used as a default value to predict locations by geostatistical extension as it provides minimum RMSPE. In this study, a huge set of groundwater data has been introduced into geostatistical analyst environment. IDW method created spatial projections using Arc GIS 10.3 software developed by ESRI to observe the distribution patterns of various physicochemical parameters and pollution indices like WQI, HEl and Cd.

\section{Results and discussion}

\subsection{Leachate characteristics}

Leachates of Jawaharnagar dumpsite were analyzed for various physicochemical parameters including heavy metals, and the data were compared with Leachate land disposal standards MoEF \& CC [2]. The significant seasonal and yearly variations in the concentrations of leachate constituents have been observed and were found beyond the prescribed permissible limits of MOEF \& CC (Table 3). Leachates collected during post-monsoon season showed higher concentrations of $\mathrm{pH}, \mathrm{TDS}, \mathrm{Cl}^{-}$and BOD5. It was also observed that the same parameters collected in the year 2015 had high concentrations compared to the year 2014 (Table 3). This could be attributed to the increased degradation and deterioration of solid wastes due to rainfall and time, respectively.

The leachates were observed amber in color with alkaline $\mathrm{pH}$ and fall within the standard limits. The increase in $\mathrm{pH}$ is mainly attributed to the decreased ionization of free volatile fatty acids, as a result of its conversion into methane and carbon-dioxide during methanogenic phase [67]. Total dissolved solids (TDS) of the leachate samples were found high compared to the standard limits. High TDS is mainly comprised of increased dissolved organic and inorganic salts. BOD5 values were found high in 2014 compared to 2015. This is due to anaerobic decomposition

Table 3 Jawaharnagar dumpsite leachates (of 2014 and 2015) compared to leachate land disposal standards MOEF [2]

\begin{tabular}{|c|c|c|c|c|c|c|c|c|c|}
\hline \multirow[t]{3}{*}{ Leachate parameters } & \multicolumn{4}{|c|}{ Leachate 1} & \multicolumn{4}{|c|}{ Leachate 2} & \multirow{3}{*}{$\begin{array}{l}\text { Leachate land } \\
\text { disposal standards } \\
\text { MOEF [2] }\end{array}$} \\
\hline & \multicolumn{2}{|l|}{2014} & \multicolumn{2}{|l|}{2015} & \multicolumn{2}{|l|}{2014} & \multicolumn{2}{|l|}{2015} & \\
\hline & Pre & Post & Pre & Post & Pre & Post & Pre & Post & \\
\hline $\mathrm{pH}$ & 8.1 & 9.0 & 8.3 & 9.0 & 8.3 & 8.6 & 8 & 8.9 & $5.5-9.0$ \\
\hline $\mathrm{EC}(\mu \mathrm{S} / \mathrm{cm})$ & 21,220 & 38,450 & 29,958 & 41,252 & 10,150 & 22,000 & 17,524 & 28,546 & - \\
\hline TDS & 14,096 & 29,633 & 25,031 & 33,043 & 13,254 & 19,452 & 24,312 & 29,245 & 2100 \\
\hline TH & 180 & 245 & 234 & 284 & 148 & 179 & 167 & 197 & - \\
\hline TA & 195 & 278 & 253 & 322 & 158 & 179 & 174 & 230 & - \\
\hline $\mathrm{Ca}^{2+}(\mathrm{mg} / \mathrm{L})$ & 39 & 120 & 42 & 148 & 15 & 80 & 42 & 97 & - \\
\hline $\mathrm{Mg}^{2+}(\mathrm{mg} / \mathrm{L})$ & 6.5 & 15 & 10 & 17 & 3.5 & 12 & 6 & 15 & - \\
\hline $\mathrm{Na}^{+}(\mathrm{mg} / \mathrm{L})$ & 2010 & 3225 & 2125 & 2547 & 1725 & 2585 & 1884 & 3210 & - \\
\hline $\mathrm{K}^{+}(\mathrm{mg} / \mathrm{L})$ & 1870 & 1102 & 1141 & 1879 & 1432 & 953 & 1021 & 1721 & - \\
\hline $\mathrm{CO}_{3}{ }^{2-}(\mathrm{mg} / \mathrm{L})$ & 79 & 195 & 91 & 214 & 45 & 69 & 57 & 76 & - \\
\hline $\mathrm{HCO}_{3}{ }^{-}(\mathrm{mg} / \mathrm{L})$ & 652 & 811 & 714 & 921 & 455 & 532 & 471 & 612 & - \\
\hline $\mathrm{NO}_{3}^{-}(\mathrm{mg} / \mathrm{L})$ & 876 & 1012 & 995 & 1100 & 615 & 944 & 752 & 1017 & - \\
\hline $\mathrm{SO}_{4}{ }^{2-}(\mathrm{mg} / \mathrm{L})$ & 141 & 150 & 150 & 164 & 114 & 125 & 146 & 155 & - \\
\hline $\mathrm{Cl}^{-}(\mathrm{mg} / \mathrm{L})$ & 6554 & 7247 & 12,266 & 45,319 & 3344 & 4655 & $11,003.6$ & 34,876 & 600 \\
\hline $\mathrm{F}^{-}(\mathrm{mg} / \mathrm{L})$ & 0.2 & 0.3 & 0.2 & 0.7 & 0.2 & 0.3 & 0.2 & 0.7 & - \\
\hline BOD5 & 996 & 991 & 490 & 436 & 520 & 518 & 323 & 318 & 100 \\
\hline COD & 10,204 & 10,200 & 7147 & 7122 & 5388 & 5379 & 3413 & 3400 & - \\
\hline T. coli $(100 \mathrm{ml})$ & $\geq 1609$ & $\geq 1609$ & $\geq 1609$ & $\geq 1609$ & $\geq 1609$ & $\geq 1609$ & $\geq 1609$ & $\geq 1609$ & - \\
\hline F. coli $(100 \mathrm{ml})$ & Present & Present & Present & Present & Present & Present & Present & Present & - \\
\hline E. coli $(100 \mathrm{ml})$ & Present & Present & Present & Present & Present & Present & Present & Present & - \\
\hline
\end{tabular}


Table 4 Jawaharnagar dumpsite leachates heavy metals compared to leachate land disposal standards MOEF [2]

\begin{tabular}{llll}
\hline $\begin{array}{l}\text { Heavy met- } \\
\text { als }(\mu \mathrm{g} / \mathrm{L})\end{array}$ & Leachate 1 & Leachate 2 & $\begin{array}{l}\text { Leachate land } \\
\text { disposal standards, } \\
\text { MOEF [2] }\end{array}$ \\
\hline $\mathrm{Al}$ & 569.9 & 490.4 & - \\
$\mathrm{As}$ & 66.3 & 35.5 & 0.2 \\
$\mathrm{Cd}$ & 1.16 & 0.98 & - \\
$\mathrm{Co}$ & 27.32 & 17.1 & - \\
$\mathrm{Fe}$ & 6550 & 5458 & - \\
$\mathrm{Cu}$ & 53.8 & 46.14 & - \\
$\mathrm{Mn}$ & 6272 & 5142 & - \\
$\mathrm{Ni}$ & 67.3 & 10.22 & - \\
$\mathrm{Pb}$ & $\mathrm{BDL}$ & $\mathrm{BDL}$ & - \\
$\mathrm{Zn}$ & 12.3 & 10.44 & - \\
\hline
\end{tabular}

of methanogenic phase where in the absence of oxygen, humic and fulvic acid compounds dominate over organic matter. Thus, the biodegradability decreases with time and age of the dumpsite [68]. Chlorides $\left(\mathrm{Cl}^{-}\right)$were also found high in the leachate samples when compared with standard limits. Chloride is one of the major constituents to determine the leachate contamination in groundwater. The main sources of chlorides in MSW leachate are food scraps and animal wastes. The presence of various metals in the leachates indicated the disposal of variety of wastes at the dumpsite. Heavy metals like arsenic (As), concentration was found above the standard limits. Dumping of arsenic containing wastes like cosmetics and personal care products (CPCP) might be responsible for the increased concentration of arsenic in groundwater. However, iron (Fe) was found predominant in the leachates (Table 4).

\subsection{Groundwater pollution monitoring}

The groundwater samples $(n=23)$ collected and analyzed for various parameters in both pre- and post-monsoon seasons for two consecutive years, i.e., 2014 and 2015 to observe the seasonal and temporal variations and were compared with WHO drinking water quality standards [69] to determine the suitability for human consumption (Tables 5 and 6). All the groundwater samples were colorless and odorless except for GW10 (Haridaspally) which is located at $1.2 \mathrm{~km}$ from the dumpsite. The $\mathrm{pH}$ of all the groundwater samples was found within the permissible range of WHO standards. EC values of all the groundwater samples were found within the WHO limits except for few samples located near the dumpsite. High conductivity is mainly due to the presence of high concentration of dissolved inorganic ions in the groundwater due to the leachate contamination [25].

The parameters like TDS, $\mathrm{TH}, \mathrm{Na}^{+}, \mathrm{NO}_{3}{ }^{-}$and $\mathrm{Cl}^{-}$were found exceeding the permissible limits of WHO standards. Municipal dumpsite leachates are the major indeed sources of high TDS, $\mathrm{Cl}^{-}$and $\mathrm{NO}_{3}{ }^{-}$in groundwater. High TDS observed might be possibly due to the presence of dissolved organic and inorganic salts of the leachates in groundwater. High concentrations of chlorides are added to the groundwater from the municipal wastes, which clearly indicate the impact of landfill leachate $[6,70]$. Other sources include farm drainage and sewage effluents [6]. High chlorination of groundwater possibly leachate derived produces trihalomethanes (THM). These chlorine byproducts trigger the production of free radicals in the body causing cell damage and are highly carcinogenic [71]. High nitrates observed in groundwater are mainly due to the leachate contamination. According to [72], major sources of nitrates include domestic sewage, runoff from agricultural fields and leachate from landfill sites.

Spatial distribution maps of TDS, $\mathrm{Cl}^{-}$and $\mathrm{NO}_{3}{ }^{-}$were prepared using IDW method in Arc GIS 10.3 software to observe the seasonal and temporal variations in groundwater $[20,73]$ due to leachate contamination (Figs. 3, 4 and 5). From the figures, the observations were made as follows:

(1) The concentrations of three parameters (TDS, $\mathrm{Cl}^{-}$ and $\mathrm{NO}_{3}^{-}$) were high during post-monsoon season in both years.

(2) The TDS, $\mathrm{Cl}^{-}$and $\mathrm{NO}_{3}{ }^{-}$concentrations in groundwater increased in 2015 compared to 2014.

(3) As the distance increased from the dumpsite, the extent of contamination has decreased.

During rainfall, the deterioration and degradation of solid wastes are high which results in increased leaching and percolation of solid waste constituents into groundwater environment. Thereby, groundwater quality is deteriorating with time which is evident from the impact of leachates. 
Table 5 Physicochemical analysis of groundwater collected around Jawaharnagar dumpsite during pre- and post-monsoon in 2014 and its comparison with WHO standards [69]

\begin{tabular}{|c|c|c|c|c|c|c|c|c|c|c|c|c|c|c|c|c|c|c|}
\hline \multirow[t]{2}{*}{ Sl. no. } & \multicolumn{2}{|l|}{$\mathrm{pH}$} & \multicolumn{2}{|l|}{$\mathrm{EC}$} & \multicolumn{2}{|l|}{ TDS } & \multicolumn{2}{|l|}{$\mathrm{TH}$} & \multicolumn{2}{|l|}{$\mathrm{Ca}^{2+}$} & \multicolumn{2}{|l|}{$\mathrm{Mg}^{2+}$} & \multicolumn{2}{|l|}{$\mathrm{Na}^{+}$} & \multicolumn{2}{|l|}{$\mathrm{K}^{+}$} & \multicolumn{2}{|c|}{$\mathrm{CO}_{3}{ }^{2-}$} \\
\hline & Pre & Post & Pre & Post & Pre & Post & Pre & Post & Pre & Post & Pre & Post & Pre & Post & Pree & Post & Pre & Post \\
\hline GW1 & 7.1 & 7.8 & 1400 & 1500 & 896 & 960 & 370 & 470 & 74 & 89 & 45 & 60 & 31 & 42 & 3 & 4 & 16 & 24 \\
\hline GW2 & 7.4 & 7.8 & 191 & 700 & 122 & 448 & 168 & 175 & 20 & 41 & 5.3 & 16 & 28 & 45 & 2 & 4 & 12 & 18 \\
\hline GW3 & 7.4 & 7.6 & 1300 & 1403 & 832 & 898 & 285 & 300 & 68 & 80 & 9.7 & 35 & 84 & 101 & 2 & 5 & 12 & 26 \\
\hline GW4 & 7.5 & 7.6 & 1400 & 1602 & 957 & 1025 & 185 & 300 & 45 & 86 & 18 & 20.6 & 95 & 149 & 2 & 4 & 15 & 25 \\
\hline GW5 & 7.1 & 7.3 & 980 & 1502 & 627 & 961 & 320 & 325 & 78 & 90 & 24 & 31 & 74 & 126 & 2 & 5 & 19 & 28 \\
\hline GW6 & 7.3 & 7.6 & 600 & 772 & 494 & 512 & 185 & 200 & 45 & 78 & 12 & 18 & 42 & 77 & 1 & 6 & 6 & 34 \\
\hline GW7 & 7.2 & 7.5 & 1000 & 1254 & 640 & 803 & 341 & 370 & 82 & 102 & 11 & 33 & 41 & 57 & 1 & 3 & 5 & 21 \\
\hline GW8 & 7.2 & 7.5 & 1495 & 1610 & 768 & 1030 & 260 & 548 & 114 & 132 & 36 & 53 & 84 & 128 & 1 & 2 & 12 & 30 \\
\hline GW9 & 7.21 & 7.3 & 1494 & 1500 & 640 & 956 & 300 & 325 & 72 & 78 & 29 & 42 & 93 & 107 & 4 & 5 & 15 & 28 \\
\hline GW10 & 7.3 & 7.6 & 1060 & 3154 & 1060 & 2018 & 315 & 610 & 73 & 220 & 14.5 & 36 & 97 & 142 & 2 & 4 & 9 & 21 \\
\hline GW11 & 7.2 & 7.5 & 2104 & 2200 & 1347 & 1408 & 380 & 492 & 320 & 332 & 13 & 21 & 142 & 226 & 2 & 3 & 6 & 16 \\
\hline GW12 & 7.1 & 7.4 & 1115 & 1200 & 714 & 768 & 207 & 290 & 32 & 50 & 20 & 31 & 98 & 134 & 3 & 5 & 6 & 9 \\
\hline GW13 & 7.2 & 7.3 & 720 & 800 & 461 & 512 & 265 & 268 & 62 & 65 & 26 & 28 & 48 & 61 & 5 & 5 & 8 & 9 \\
\hline GW14 & 7.3 & 7.6 & 210 & 711 & 120 & 440 & 200 & 202 & 21 & 41 & 5 & 17 & 27 & 46 & 2 & 4 & 13 & 20 \\
\hline GW15 & 7.2 & 7.6 & 1100 & 1221 & 460 & 474 & 234 & 250 & 83 & 105 & 12 & 32 & 42 & 57 & 1 & 2 & 6 & 22 \\
\hline GW16 & 7.2 & 7.3 & 982 & 1000 & 625 & 1021 & 319 & 326 & 78 & 91 & 25 & 33 & 75 & 124 & 2 & 4 & 20 & 35 \\
\hline GW17 & 7.2 & 7.4 & 1285 & 1301 & 1014 & 1133 & 187 & 200 & 47 & 60 & 12.1 & 19 & 83 & 164 & 2 & 3 & 19 & 24 \\
\hline GW18 & 7.1 & 7.3 & 1248 & 1257 & 452 & 631 & 165 & 178 & 36 & 43 & 14 & 28 & 52 & 67 & 1 & 3 & 14 & 22 \\
\hline GW19 & 7.2 & 7.4 & 1247 & 1320 & 435 & 611 & 169 & 177 & 42 & 54 & 21 & 30 & 45 & 51 & 2 & 2 & 12 & 21 \\
\hline GW20 & 7.2 & 7.2 & 1324 & 1421 & 512 & 695 & 174 & 182 & 34 & 42 & 24 & 33 & 39 & 44 & 2 & 3 & 9 & 25 \\
\hline GW21 & 7.3 & 7.4 & 1120 & 1226 & 455 & 524 & 159 & 168 & 44 & 58 & 22 & 34 & 33 & 53 & 1 & 2 & 11 & 23 \\
\hline GW22 & 7.1 & 7.3 & 1210 & 1342 & 412 & 533 & 168 & 184 & 39 & 47 & 21 & 44 & 52 & 60 & 2 & 5 & 18 & 25 \\
\hline GW23 & 7.2 & 7.4 & 1262 & 1346 & 152 & 245 & 155 & 174 & 41 & 56 & 30 & 42 & 29 & 38 & 2 & 4 & 12 & 20 \\
\hline Minimum & 7.1 & 7.2 & 191 & 700 & 120 & 245 & 155 & 168 & 20 & 41 & 5 & 16 & 27 & 38 & 1 & 2 & 5 & 9 \\
\hline Maximum & 7.5 & 7.8 & 2104 & 3154 & 1347 & 2018 & 380 & 610 & 320 & 332 & 45 & 60 & 142 & 226 & 5 & 6 & 20 & 35 \\
\hline Mean & 7.2 & 7.5 & 1123.8 & 1362.7 & 617.2 & 809.0 & 239.6 & 291.9 & 67.5 & 88.7 & 19.5 & 32.0 & 62.3 & 91.3 & 2.0 & 3.8 & 12 & 22.9 \\
\hline WHO [69] & $6.5-8.5$ & & 1500 & & 500 & & 500 & & 75 & & 50 & & 200 & & 12 & & NA & \\
\hline \multirow[t]{2}{*}{ Sl. no. } & \multicolumn{3}{|c|}{$\mathrm{HCO}^{3-}$} & \multicolumn{3}{|l|}{$\mathrm{SO}_{4}{ }^{2-}$} & \multicolumn{3}{|l|}{$\mathrm{Cl}^{-}$} & \multicolumn{3}{|l|}{$\mathrm{F}^{-}$} & $\mathrm{NO}^{3-}$ & & & TA & & \\
\hline & Pre & & Post & Pre & Post & & Pre & Post & & Pre & Pos & & Pre & Post & & Pre & & Post \\
\hline GW1 & 98 & & 350 & 132 & 174 & & 337 & 352 & & 0.5 & 0.8 & & 74 & 164 & & 100 & & 293 \\
\hline GW2 & 128 & & 153 & 80 & 95 & & 36 & 43 & & 0.6 & 1.2 & & 12 & 38 & & 125 & & 205 \\
\hline GW3 & 85.4 & & 378 & 135 & 154 & & 260 & 315 & & 1.4 & 1.6 & & 39 & 58 & & 95 & & 330 \\
\hline GW4 & 100 & & 158 & 120 & 158 & & 320 & 347 & & 1.1 & 1.3 & & 73 & 91 & & 102 & & 239 \\
\hline GW5 & 79 & & 360 & 110 & 133 & & 290 & 340 & & 0.4 & 0.9 & & 56 & 67 & & 75 & & 350 \\
\hline GW6 & 104 & & 256 & 74 & 141 & & 74 & 141 & & 1.2 & 1 & & 12 & 26 & & 95 & & 251 \\
\hline GW7 & 140 & & 214 & 132 & 246 & & 132 & 246 & & 0.8 & 1 & & 125 & 190 & & 125 & & 250 \\
\hline GW8 & 390 & & 415 & 125 & 173 & & 337 & 479 & & 0.9 & 1 & & 15 & 22 & & 340 & & 390 \\
\hline GW9 & 284 & & 293 & 120 & 146 & & 121 & 213 & & 0.8 & 1.4 & & 62 & 156 & & 256 & & 364 \\
\hline GW10 & 280 & & 299 & 143 & 152 & & 957 & 1138 & & 0.9 & 1 & & 32 & 44 & & 245 & & 280 \\
\hline GW11 & 120 & & 171 & 123 & 152 & & 820 & 851 & & 0.4 & 0.6 & & 64 & 75 & & 130 & & 150 \\
\hline GW12 & 142 & & 156 & 120 & 132 & & 156 & 220 & & 0.4 & 1.2 & & 75 & 76 & & 126 & & 143 \\
\hline GW13 & 98 & & 112 & 82 & 96 & & 145 & 251 & & 1.3 & 1.5 & & 165 & 170 & & 165 & & 170 \\
\hline GW14 & 127 & & 153 & 81 & 90 & & 35 & 43 & & 0.6 & 1.2 & & 12 & 39 & & 125 & & 205 \\
\hline GW15 & 142 & & 210 & 125 & 200 & & 125 & 240 & & 0.7 & 1 & & 70 & 84 & & 120 & & 245 \\
\hline GW16 & 200 & & 378 & 112 & 130 & & 287 & 344 & & 0.4 & 0.9 & & 56 & 66 & & 77 & & 345 \\
\hline GW17 & 80 & & 354 & 156 & 191 & & 333 & 341 & & 0.2 & 1 & & 57 & 81 & & 181 & & 394 \\
\hline GW18 & 82 & & 125 & 75 & 84 & & 40 & 51 & & 0.5 & 0.6 & & 41 & 54 & & 95 & & 124 \\
\hline
\end{tabular}


Table 5 (continued)

\begin{tabular}{|c|c|c|c|c|c|c|c|c|c|c|c|c|}
\hline \multirow[t]{2}{*}{ SI. no. } & \multicolumn{2}{|l|}{$\mathrm{HCO}^{3-}$} & \multicolumn{2}{|l|}{$\mathrm{SO}_{4}{ }^{2-}$} & \multicolumn{2}{|l|}{$\mathrm{Cl}^{-}$} & \multicolumn{2}{|l|}{$\mathrm{F}^{-}$} & \multicolumn{2}{|c|}{$\mathrm{NO}^{3-}$} & \multicolumn{2}{|l|}{ TA } \\
\hline & Pre & Post & Pre & Post & Pre & Post & Pre & Post & Pre & Post & Pre & Post \\
\hline GW19 & 74 & 132 & 64 & 70 & 36 & 45 & 0.4 & 0.5 & 39 & 50 & 121 & 136 \\
\hline GW20 & 81 & 154 & 71 & 87 & 33 & 41 & 0.5 & 0.6 & 45 & 56 & 112 & 144 \\
\hline GW21 & 78 & 122 & 73 & 92 & 45 & 57 & 0.4 & 0.6 & 47 & 55 & 135 & 157 \\
\hline GW22 & 85 & 136 & 70 & 81 & 36 & 47 & 0.2 & 0.4 & 33 & 47 & 128 & 155 \\
\hline GW23 & 76 & 140 & 77 & 82 & 42 & 50 & 0.2 & 0.3 & 37 & 53 & 131 & 142 \\
\hline Minimum & 74 & 112 & 64 & 70 & 33 & 41 & 0.2 & 0.3 & 12 & 22 & 75 & 124 \\
\hline Maximum & 390 & 450 & 156 & 246 & 957 & 1138 & 1.4 & 1.6 & 165 & 190 & 340 & 394 \\
\hline Mean & 133.6 & 226.9 & 104.3 & 133.0 & 217.3 & 269.3 & 0.6 & 0.9 & 54 & 76.6 & 139.3 & 237.5 \\
\hline WHO [69] & NA & & 250 & & 250 & & 1.5 & & 45 & & 500 & \\
\hline
\end{tabular}

Table 6 Physicochemical analysis of groundwater collected around Jawaharnagar dumpsite during pre- and post-monsoon in 2015 and its comparison with WHO standards [69]

\begin{tabular}{|c|c|c|c|c|c|c|c|c|c|c|c|c|c|c|c|c|c|c|}
\hline \multirow[t]{2}{*}{ SI. no. } & \multicolumn{2}{|l|}{$\mathrm{pH}$} & \multicolumn{2}{|l|}{$\mathrm{EC}$} & \multicolumn{2}{|l|}{ TDS } & \multicolumn{2}{|l|}{$\mathrm{TH}$} & \multicolumn{2}{|l|}{$\mathrm{Ca}^{2+}$} & \multicolumn{2}{|c|}{$\mathrm{Mg}^{2+}$} & \multicolumn{2}{|l|}{$\mathrm{Na}^{+}$} & \multicolumn{2}{|l|}{$\mathrm{K}^{+}$} & \multicolumn{2}{|c|}{$\mathrm{CO}_{3}{ }^{2-}$} \\
\hline & Pre & Post & Pre & Post & Pre & Post & Pre & Post & Pre & Post & Pre & Post & Pre & Post & Pre & Post & Pre & Post \\
\hline GW1 & 7.3 & 7.7 & 1467 & 1584 & 942 & 997 & 382 & 487 & 80 & 91 & 54 & 78 & 43 & 56 & 5 & 7 & 23 & 32 \\
\hline GW2 & 7.3 & 7.8 & 489 & 768 & 350 & 475 & 110 & 172 & 25 & 46 & 17 & 25 & 35 & 57 & 4 & 8 & 15 & 24 \\
\hline GW3 & 7.5 & 7.7 & 1298 & 1399 & 859 & 912 & 260 & 310 & 72 & 85 & 12 & 40 & 95 & 124 & 3 & 9 & 20 & 31 \\
\hline GW4 & 7.4 & 7.7 & 1534 & 1643 & 981 & 1287 & 210 & 321 & 54 & 88 & 23 & 35 & 112 & 168 & 4 & 6 & 21 & 61 \\
\hline GW5 & 7.3 & 7.7 & 1345 & 1560 & 687 & 995 & 250 & 334 & 81 & 95 & 30 & 44 & 87 & 145 & 3 & 7 & 12 & 40 \\
\hline GW6 & 7.3 & 7.8 & 630 & 824 & 490 & 538 & 210 & 257 & 53 & 84 & 15 & 24 & 51 & 82 & 2 & 5 & 10 & 55 \\
\hline GW7 & 7.4 & 7.6 & 1200 & 1301 & 697 & 829 & 325 & 388 & 42 & 6 & 15 & 39 & 52 & 69 & 2 & 5 & 17 & 28 \\
\hline GW8 & 7.4 & 7.7 & 1387 & 1685 & 810 & 1234 & 278 & 584 & 125 & 147 & 43 & 61 & 98 & 139 & 3 & 6 & 18 & 37 \\
\hline GW9 & 7.1 & 7.4 & 1282 & 1500 & 784 & 980 & 241 & 269 & 29 & 78 & 38 & 46 & 102 & 112 & 6 & 10 & 28 & 51 \\
\hline GW10 & 7.4 & 7.8 & 1341 & 3214 & 1217 & 2107 & 242 & 758 & 16 & 41 & 23 & 54 & 108 & 165 & 3 & 5 & 15 & 27 \\
\hline GW11 & 7.1 & 7.4 & 2245 & 2284 & 1385 & 1478 & 410 & 545 & 140 & 152 & 14 & 26 & 154 & 253 & 3 & 7 & 14 & 27 \\
\hline GW12 & 7.2 & 7.4 & 1285 & 1546 & 754 & 802 & 230 & 324 & 28 & 61 & 31 & 40 & 121 & 147 & 3 & 6 & 10 & 17 \\
\hline GW13 & 7.1 & 7.2 & 621 & 785 & 497 & 562 & 279 & 355 & 71 & 78 & 32 & 36 & 56 & 74 & 5 & 7 & 14 & 28 \\
\hline GW14 & 7.3 & 7.8 & 489 & 768 & 352 & 475 & 110 & 172 & 26 & 47 & 18 & 26 & 35 & 57 & 4 & 8 & 16 & 24 \\
\hline GW15 & 7.4 & 7.5 & 1201 & 1300 & 697 & 829 & 324 & 388 & 43 & 87 & 16 & 40 & 53 & 70 & 2 & 5 & 17 & 27 \\
\hline GW16 & 7.3 & 7.7 & 1344 & 1560 & 687 & 995 & 250 & 334 & 81 & 95 & 31 & 44 & 89 & 105 & 3 & 7 & 13 & 28 \\
\hline GW17 & 7.4 & 7.6 & 1623 & 1812 & 1200 & 1285 & 203 & 250 & 51 & 67 & 15 & 27 & 95 & 177 & 4 & 6 & 35 & 53 \\
\hline GW18 & 7.2 & 7.5 & 478 & 678 & 352 & 487 & 115 & 175 & 24 & 45 & 16 & 23 & 41 & 52 & 2 & 4 & 22 & 30 \\
\hline GW19 & 7.1 & 7.4 & 470 & 689 & 412 & 521 & 230 & 280 & 30 & 46 & 24 & 36 & 36 & 58 & 3 & 4 & 16 & 25 \\
\hline GW20 & 7.3 & 7.6 & 512 & 720 & 382 & 475 & 212 & 241 & 52 & 71 & 20 & 38 & 34 & 56 & 3 & 5 & 22 & 41 \\
\hline GW21 & 7.2 & 7.5 & 479 & 723 & 374 & 481 & 221 & 253 & 35 & 51 & 30 & 41 & 39 & 50 & 2 & 5 & 15 & 32 \\
\hline GW22 & 7.1 & 7.5 & 475 & 721 & 385 & 492 & 290 & 321 & 42 & 52 & 24 & 36 & 44 & 53 & 3 & 6 & 20 & 30 \\
\hline GW23 & 7.2 & 7.3 & 480 & 689 & 368 & 474 & 248 & 312 & 44 & 54 & 26 & 36 & 42 & 55 & 3 & 5 & 17 & 35 \\
\hline Minimum & 7.1 & 7.2 & 470 & 678 & 350 & 474 & 110 & 172 & 16 & 6 & 12 & 23 & 34 & 50 & 2 & 4 & 10 & 17 \\
\hline Maximum & 7.5 & 7.8 & 2245 & 3214 & 1385 & 2107 & 410 & 758 & 140 & 152 & 54 & 78 & 154 & 253 & 6 & 10 & 35 & 61 \\
\hline Mean & 7.3 & 7.6 & 1029.3 & 1293.6 & 681 & 857 & 244.8 & 340.4 & 54.1 & 72.5 & 24.7 & 38.9 & 74.5 & 101 & 3.3 & 6.2 & 17.8 & 34 \\
\hline WHO [69] & $6.5-8.5$ & & 1500 & & 500 & & 500 & & 75 & & 50 & & 200 & & 12 & & NA & \\
\hline
\end{tabular}


Table 6 (continued)

\begin{tabular}{|c|c|c|c|c|c|c|c|c|c|c|c|c|}
\hline \multirow[t]{2}{*}{ Sl. no. } & \multicolumn{2}{|c|}{$\mathrm{HCO}^{3-}$} & \multicolumn{2}{|l|}{$\mathrm{SO}_{4}{ }^{2-}$} & \multicolumn{2}{|l|}{$\mathrm{Cl}^{-}$} & \multicolumn{2}{|l|}{$\mathrm{F}^{-}$} & \multicolumn{2}{|l|}{$\mathrm{NO}^{3-}$} & \multicolumn{2}{|l|}{$\mathrm{TA}$} \\
\hline & Pre & Post & Pre & Post & Pre & Post & Pre & Post & Pre & Post & Pre & Post \\
\hline GW1 & 40.3 & 384 & 135 & 240 & 340.3 & 440 & 0.5 & 0.6 & 172 & 190 & 120 & 315 \\
\hline GW2 & 135 & 174 & 110.4 & 115 & 49.6 & 202 & 0.9 & 1.9 & 49 & 94 & 144 & 231 \\
\hline GW3 & 95 & 412 & 173 & 198 & 262.2 & 355 & 1.6 & 1.7 & 42 & 56 & 114 & 355 \\
\hline GW4 & 124 & 168 & 111 & 145 & 319 & 355 & 0.7 & 1.2 & 81 & 95 & 134 & 266 \\
\hline GW5 & 88 & 195 & 112 & 145 & 287 & 351 & 0.6 & 1 & 100 & 143 & 97 & 384 \\
\hline GW6 & 125 & 310 & 110 & 134 & 78 & 121 & 1.1 & 1.5 & 20 & 28 & 112 & 284 \\
\hline GW7 & 167 & 235 & 150 & 195 & 127.6 & 202 & 0.7 & 0.9 & 142 & 187 & 147 & 297 \\
\hline GW8 & 421 & 433 & 164 & 250 & 340 & 364 & 1 & 1 & 35 & 56 & 365 & 415 \\
\hline GW9 & 292 & 331 & 114 & 168 & 128 & 294 & 1.3 & 1.6 & 120 & 162 & 294 & 375 \\
\hline GW10 & 294 & 347 & 138 & 160 & 910 & 1111.3 & 0.6 & 1 & 36 & 54 & 284 & 347 \\
\hline GW11 & 135 & 184 & 132 & 190 & 817 & 859 & 0.5 & 0.6 & 132 & 155 & 145 & 187 \\
\hline GW12 & 161 & 178 & 117 & 129.6 & 223 & 230.4 & 1.1 & 1.3 & 73 & 77 & 145 & 164 \\
\hline GW13 & 121 & 142 & 106 & 112 & 134.7 & 266 & 1.3 & 1.6 & 166 & 170 & 114 & 137 \\
\hline GW14 & 135 & 174 & 110 & 115 & 50 & 200 & 0.9 & 1.9 & 49 & 94 & 114 & 231 \\
\hline GW15 & 165 & 238 & 150 & 195 & 128 & 202 & 0.7 & 0.9 & 140 & 188 & 145 & 294 \\
\hline GW16 & 89 & 190 & 112 & 145 & 300 & 351 & 0.6 & 1 & 100 & 142 & 97 & 385 \\
\hline GW17 & 254 & 412 & 160 & 208 & 320 & 355 & 0.5 & 0.6 & 104 & 167 & 203 & 412 \\
\hline GW18 & 120 & 152 & 130 & 235 & 300 & 350 & 0.4 & 0.5 & 52 & 90 & 121 & 300 \\
\hline GW19 & 89 & 165 & 102 & 114 & 90 & 125 & 0.5 & 0.7 & 50 & 92 & 142 & 212 \\
\hline GW20 & 85 & 112 & 112 & 132 & 97 & 142 & 0.6 & 0.7 & 82 & 90 & 102 & 245 \\
\hline GW21 & 52 & 100 & 113 & 135 & 75 & 156 & 0.4 & 0.6 & 51 & 93 & 120 & 240 \\
\hline GW22 & 112 & 158 & 100 & 124 & 78 & 136 & 0.5 & 0.6 & 50 & 90 & 98 & 180 \\
\hline GW23 & 82 & 145 & 110 & 120 & 92 & 212 & 0.4 & 0.7 & 48 & 91 & 92 & 125 \\
\hline Minimum & 40.3 & 100 & 100 & 112 & 49.6 & 121 & 0.4 & 0.5 & 20 & 28 & 92 & 125 \\
\hline Maximum & 421 & 433 & 173 & 250 & 910 & 1111.2 & 1.6 & 1.9 & 172 & 190 & 365 & 415 \\
\hline Mean & 147 & 232.1 & 124.8 & 161.1 & 241.1 & 320.9 & 0.8 & 1.0 & 82.3 & 113.2 & 150 & 277.4 \\
\hline WHO [69] & NA & & 250 & & 250 & & 1.5 & & 45 & & 500 & \\
\hline
\end{tabular}

\subsection{Water quality index (WQI)}

Water quality index (WQI) was calculated for groundwater samples $(n=23)$ collected during pre- and post-monsoon seasons of year 2014 and 2015 and were presented (Table 7). The percentages of groundwater samples falling in different water quality status were shown (Table 8 ). It indicated that majority $(60 \%)$ of the groundwater samples were falling in the "Poor" water class range (100-200). Water samples show a good pre- and post-monsoon water quality of $39 \%$ and $26 \%$ in $2014 ; 39 \%$ and $30 \%$ in 2015. GWQI spatial distribution maps were created using IDW interpolation method to observe the water quality patterns in connection with leachate pollutants. From the figures, it is clear that as the distance increased from the dumpsite the groundwater was not influenced by the leachates. On the other hand, the groundwater wells in the vicinity of the dumpsite (approx. $2 \mathrm{~km}$ ) were highly contaminated (Fig. 6). This study demonstrates that the use of GIS and WQI methods could provide useful information for water quality assessment.

\subsection{Heavy metal pollution indices}

It was observed from the literature [74] that only $0.02 \%$ of heavy metals leaches out from the total heavy metals 

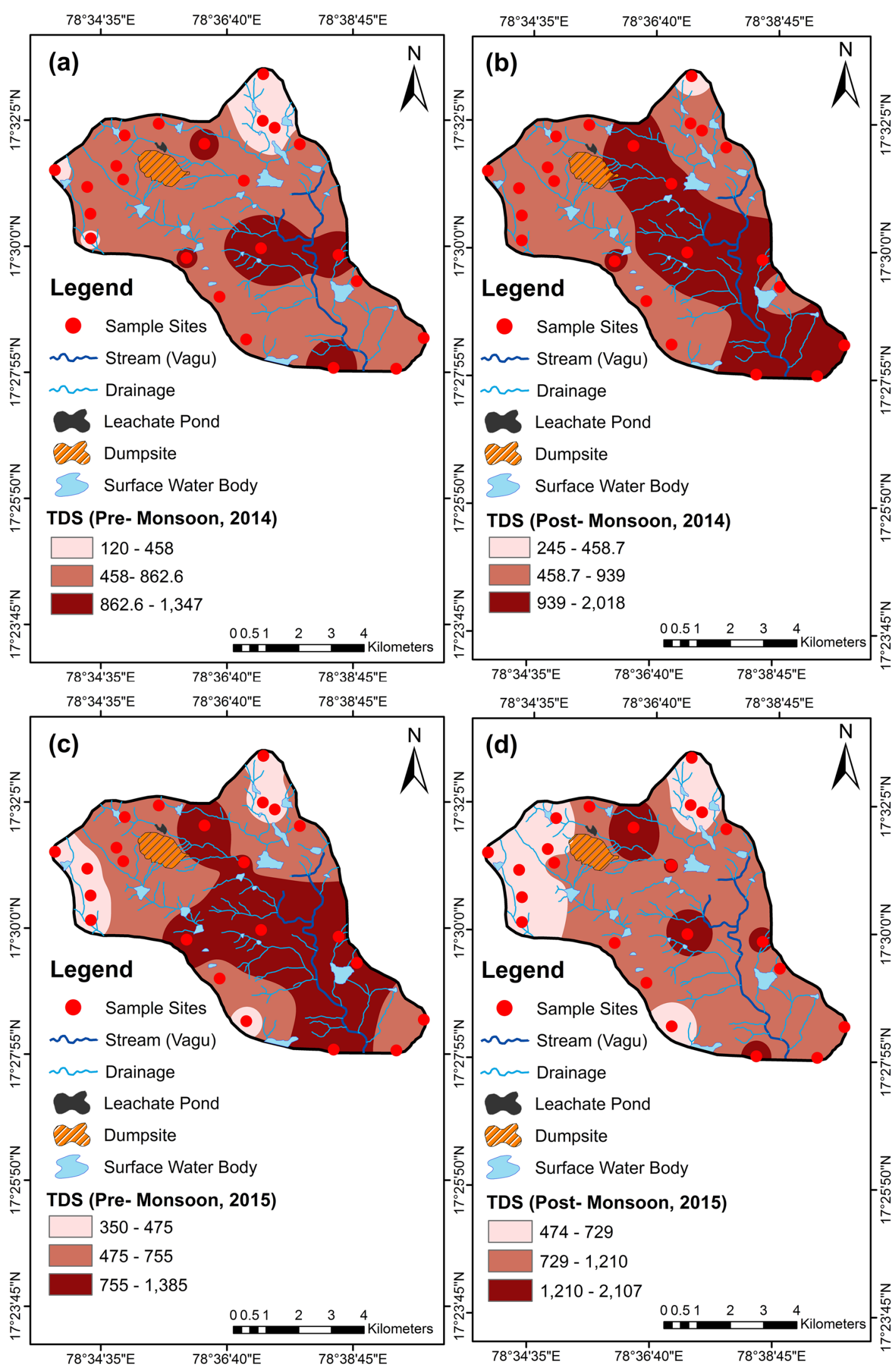

Fig. 3 Spatial distribution map of total dissolved solids (TDS) in groundwater 

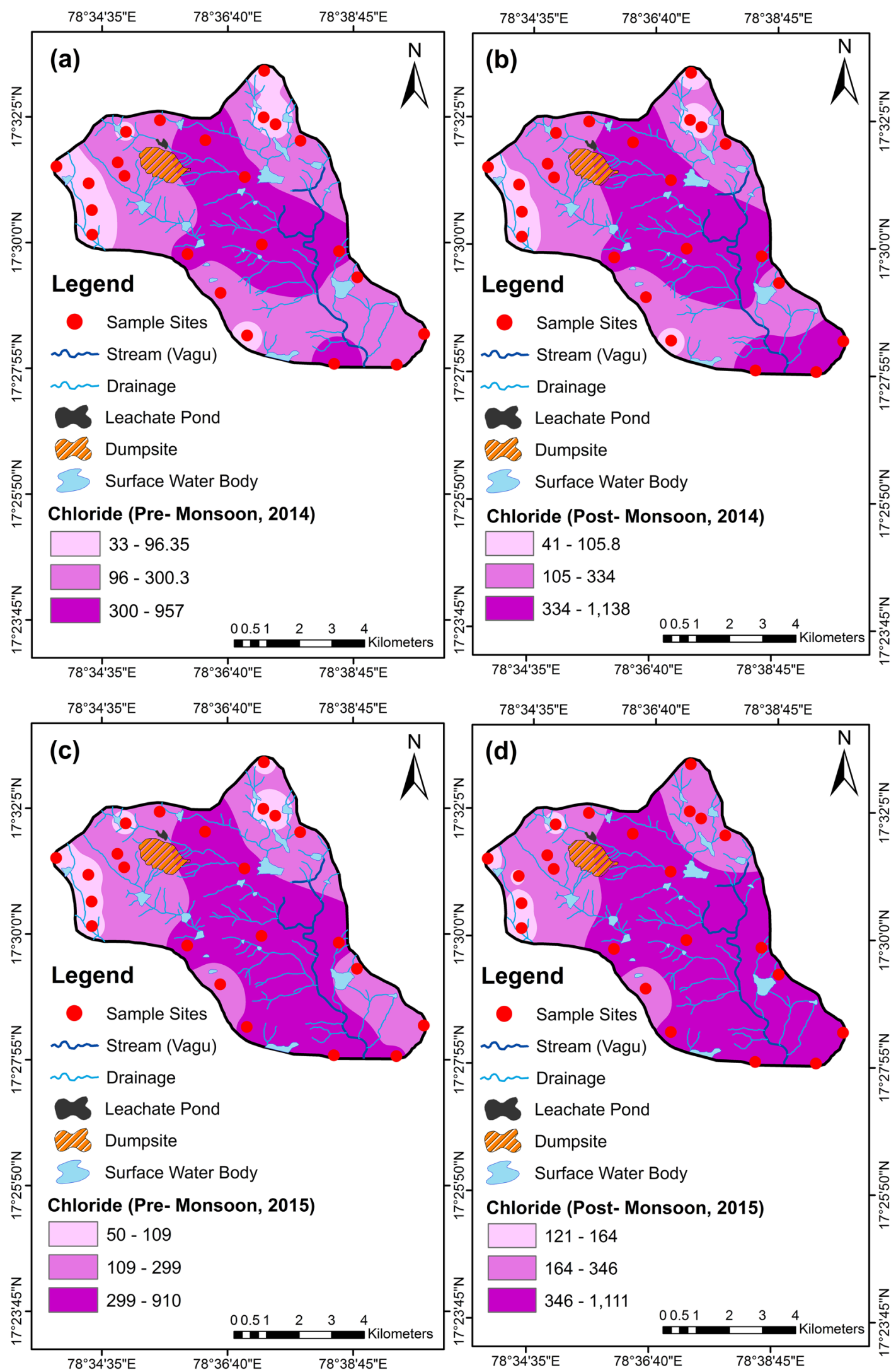

Fig. 4 Spatial distribution map of chlorides $\left(\mathrm{Cl}^{-}\right)$in groundwater 

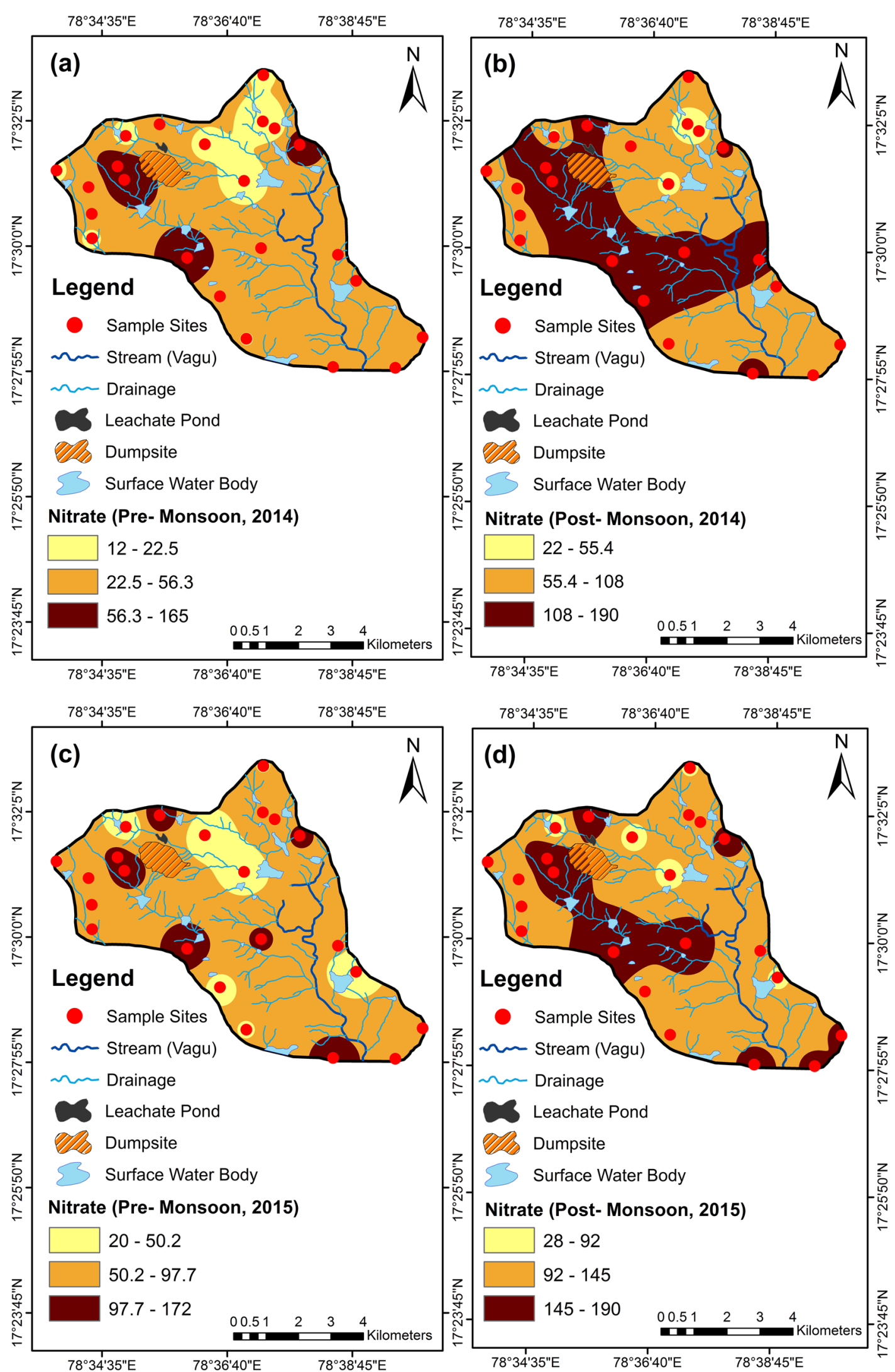

Fig. 5 Spatial distribution map of nitrates $\left(\mathrm{NO}_{3}{ }^{-}\right)$in groundwater 
Table 7 Water quality index (WQI) values of groundwater samples collected in 2014 and 2015

\begin{tabular}{|c|c|c|c|c|}
\hline \multirow[t]{3}{*}{ S. no. } & \multicolumn{4}{|c|}{ Water quality index (WQI) values } \\
\hline & \multicolumn{2}{|l|}{2014} & \multicolumn{2}{|l|}{2015} \\
\hline & Pre & Post & Pre & Post \\
\hline GW1 & 110.2 & 166 & 156.9 & 184.9 \\
\hline GW2 & 47.6 & 49 & 66.5 & 116.5 \\
\hline GW3 & 107.1 & 127 & 113.4 & 132.5 \\
\hline GW4 & 121.6 & 139 & 117 & 153.7 \\
\hline GW5 & 86.7 & 118 & 110.9 & 160.1 \\
\hline GW6 & 69 & 64 & 70.1 & 82 \\
\hline GW7 & 119.4 & 169 & 130.5 & 168.4 \\
\hline GW8 & 120 & 119 & 102.4 & 146.4 \\
\hline GW9 & 93.4 & 162 & 132 & 174.8 \\
\hline GW10 & 113 & 187 & 130.2 & 202.4 \\
\hline GW11 & 142.9 & 161 & 177.2 & 206.6 \\
\hline GW12 & 107.7 & 102 & 109.4 & 121.3 \\
\hline GW13 & 136 & 145 & 139 & 155 \\
\hline GW14 & 48 & 49 & 67 & 117 \\
\hline GW15 & 120.3 & 168 & 112 & 168 \\
\hline GW16 & 86 & 118.2 & 136.2 & 160 \\
\hline GW17 & 102.1 & 138 & 112 & 180 \\
\hline GW18 & 94.2 & 93 & 96 & 98 \\
\hline GW19 & 88.4 & 94 & 98 & 100 \\
\hline GW20 & 77.9 & 82 & 89 & 92 \\
\hline GW21 & 85 & 91 & 95 & 96 \\
\hline GW22 & 78 & 87 & 87 & 94 \\
\hline GW23 & 48.3 & 48 & 52 & 55 \\
\hline
\end{tabular}

Table 8 Classification of pre-monsoon and post-monsoon groundwater quality based on WQI value (2014 and 2015)

\begin{tabular}{|c|c|c|c|c|c|}
\hline \multirow[t]{3}{*}{ WQI value } & \multirow[t]{3}{*}{ Water quality } & \multicolumn{2}{|l|}{2014} & \multicolumn{2}{|l|}{2015} \\
\hline & & $\begin{array}{l}\% \text { of GW } \\
\text { samples }\end{array}$ & $\begin{array}{l}\% \text { of GW } \\
\text { samples }\end{array}$ & $\begin{array}{l}\% \text { of GW } \\
\text { samples }\end{array}$ & $\begin{array}{l}\% \text { of GW } \\
\text { samples }\end{array}$ \\
\hline & & Pre & Post & Pre & Post \\
\hline$<50$ & Excellent & $13 \%$ & $13 \%$ & Nil & Nil \\
\hline $50-100$ & Good & $39 \%$ & $26 \%$ & $39 \%$ & $30 \%$ \\
\hline $100-200$ & Poor & $47 \%$ & $60 \%$ & $60 \%$ & $60 \%$ \\
\hline $200-300$ & Very poor & $\mathrm{Nil}$ & Nil & Nil & $8 \%$ \\
\hline$>300$ & Unsuitable & Nil & Nil & Nil & Nil \\
\hline
\end{tabular}

deposited at landfill at the period of 30 years, so low concentrations of heavy metals are seen in methanogenic leachate. Therefore, all the groundwater samples were also analyzed for heavy metals like arsenic (As), cadmium $(\mathrm{Cd})$, iron $(\mathrm{Fe})$, copper $(\mathrm{Cu})$, manganese $(\mathrm{Mn})$, nickel $(\mathrm{Ni})$, zinc ( $\mathrm{Zn}$ ) only for 1 year, i.e., 2015 during pre-monsoon to understand their leachability in the study area.

Heavy metal pollution indices such as $\mathrm{HEl}$ and $\mathrm{Cd}$ were computed and presented (Table 9). According to HEl heavy metal index method, $82 \%$ of the samples fall in low-pollution class, $8 \%$ of the samples fall in medium pollution class and remaining $8 \%$ fall in high-pollution class. According to degree of contamination (Cd) factor, $91 \%$ of the groundwater samples fall in low-pollution class and $8 \%$ of the samples fall in high-pollution class (Table 10). The spatial distribution pattern of $\mathrm{HEl}$ and $\mathrm{Cd}$ of all the groundwater samples indicated that heavy metals were highly concentrated in the groundwater samples located in the vicinity than away from the dumpsite (Figs. 7 and 8).

Pearson's correlation was carried out between individual heavy metal parameters and pollution indices in order to identify the main contributing heavy metals to pollution indices (Table 11). It suggested that Fe and Mn were the significant contributing parameters as $\mathrm{Cd}$ and $\mathrm{HEl}$ strongly correlated with Fe $(r=0.881)$ and $\mathrm{Mn}(r=0.945)$. Fe and Mn positively correlated $(r=0.706)$ with each other indicating the similar source of leachate contaminating the groundwater. Further, $\mathrm{Cd}$ and $\mathrm{HEl}$ correlation is significant $(r=0.998)$ where the results show similar trends with high concentrations of Fe and Mn.

The cumulative concentration of heavy metals $(\mathrm{As}+\mathrm{Cd}+\mathrm{Fe}+\mathrm{Cu}+\mathrm{Mn}+\mathrm{Zn})$ load versus $\mathrm{pH}$ in the leachates and in the groundwater was plotted (Fig. 9) [75, 76]. Majority of the samples (56\%) were classified as near neutral-low metal. $24 \%$ of the samples were classified as near neutral-high metal. However, groundwater samples (3\%) located less than $2 \mathrm{~km}$ distance from the dumpsite show neutral $\mathrm{pH}$-extreme metal content similar to what was observed in leachates. This is further confirming that leachates are infiltrating into the groundwater system of the study area.

The distribution of the heavy metals in groundwater was observed as follows: Fe (509.2 ppb) $>M n$ 

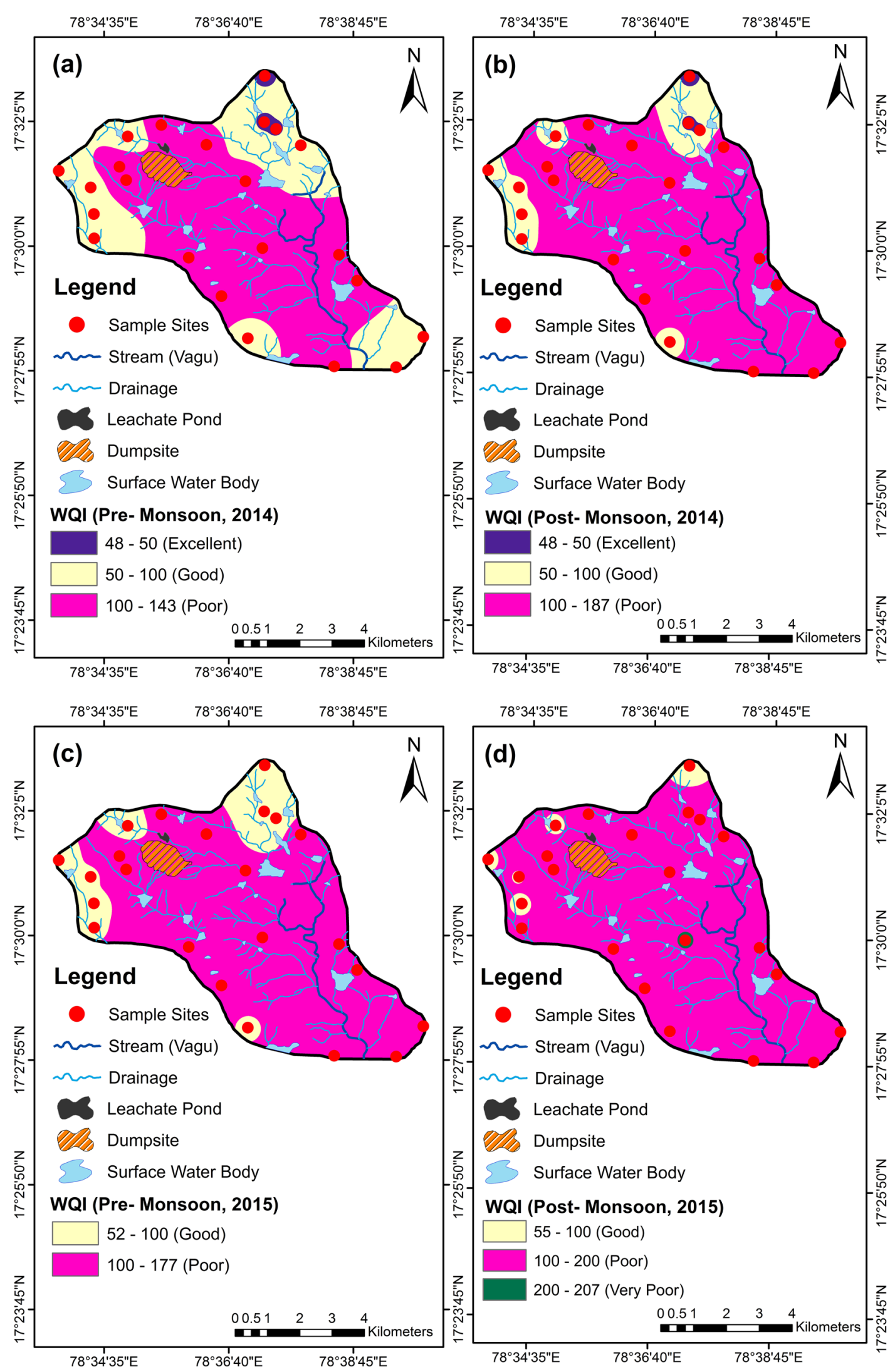

Fig. 6 Spatial distribution map of water quality index (WQI) of groundwater 
Table 9 Heavy metals, HEI and $\mathrm{Cd}$ values of groundwater samples collected around the dumpsite

\begin{tabular}{|c|c|c|c|c|c|c|c|c|c|}
\hline S. no. & $\mathrm{As}^{*}$ & $C d^{*}$ & $\mathrm{Fe}^{*}$ & $\mathrm{Cu}^{*}$ & $M n^{*}$ & $\mathrm{Zn}^{*}$ & $\mathrm{HEl}^{*}$ & $\mathrm{Cd}^{*}$ & Metal load \\
\hline GW1 & 35.9 & 0.73 & bdl & 4.7 & 29 & bdl & 1.54 & 2.45 & 0.07 \\
\hline GW2 & bdl & 0.78 & bdl & 3.1 & bdl & bdl & 0.26 & 1.73 & 0.0038 \\
\hline GW3 & bdl & 0.3 & bdl & 5.8 & bdl & bdl & 0.106 & 1.89 & 0.0061 \\
\hline GW4 & 9.3 & 0.66 & bdl & 16.6 & bdl & 83.9 & 0.438 & 2.59 & 0.1104 \\
\hline GW5 & bdl & bdl & bdl & 1.2 & 26.3 & bdl & 0.527 & 1.46 & 0.0275 \\
\hline GW6 & bdl & 1.16 & bdl & 2.39 & bdl & 93.6 & 0.401 & 2.58 & 0.097 \\
\hline GW7 & 26.6 & 0.72 & 2245 & 6.12 & 36.5 & 705.5 & 17.28 & 16.95 & 3.24 \\
\hline GW8 & bdl & 0.8 & bdl & 11.62 & 466.8 & bdl & 9.6 & 10 & 0.479 \\
\hline GW9 & bdl & 0.148 & bdl & bdl & bdl & bdl & 0.149 & 0.95 & 0.00014 \\
\hline GW10 & bdl & bdl & 3952 & 2.6 & 2353 & bdl & 66.8 & 66.8 & 6.3 \\
\hline GW11 & bdl & 0.74 & bdl & 1.89 & bdl & bdl & 0.38 & 2.6 & 0.0093 \\
\hline GW12 & bdl & 1.06 & bdl & 2.85 & 21 & 134.1 & 0.48 & 2.8 & 0.159 \\
\hline GW13 & bdl & 0.68 & 3234 & 9.15 & 61.7 & 1217 & 17.88 & 17.8 & 4.52 \\
\hline GW14 & bdl & 0.78 & bdl & 3.1 & bdl & bdl & 0.26 & 1.73 & 0.0038 \\
\hline GW15 & bdl & bdl & 2234 & 2 & 2121 & bdl & 42.44 & 42.41 & 2.12 \\
\hline GW16 & bdl & bdl & bdl & 1.2 & 26.3 & bdl & 0.527 & 1.46 & 0.027 \\
\hline GW17 & bdl & bdl & bdl & bdl & bdl & bdl & 0 & 0 & 0 \\
\hline GW18 & bdl & bdl & 36 & 1.2 & bdl & bdl & 0.18 & 0.17 & 0.0372 \\
\hline GW19 & bdl & bdl & 11 & 2 & bdl & bdl & 0.169 & 2.74 & 0.018 \\
\hline GW20 & bdl & 0.4 & bdl & 2.1 & bdl & bdl & 0.135 & 1.85 & 0.0025 \\
\hline GW21 & bdl & bdl & bdl & 1.1 & bdl & bdl & 1.1 & 0.99 & 0.0011 \\
\hline GW22 & bdl & bdl & bdl & 1 & bdl & bdl & 1 & 0.9 & 0.001 \\
\hline GW23 & bdl & bdl & bdl & 0.98 & bdl & bdl & 0.98 & 0.999 & 0.00098 \\
\hline Mean & 6.9 & 0.44 & 948.8 & 7.3 & 662.2 & 90.27 & & & \\
\hline WHO [69] & 10 & 3 & 50 & 2000 & 500 & 3000 & & & \\
\hline MAC & 50 & 3 & 200 & 1000 & 50 & 5000 & & & \\
\hline
\end{tabular}

*All parameters are expressed in $\mu \mathrm{g} / \mathrm{L}$
Table 10 Classification of groundwater samples based on $\mathrm{HEI}$ and Cd indices

S. no. Index method Class Extent of pollution \% of GW samples (pre 2015)

\begin{tabular}{lllll}
\hline 1 & HEI & $<27$ & Low & 82 \\
& & $27-54$ & Medium & 8 \\
& $>54$ & High & 8 \\
$2 \quad \mathrm{Cd}$ & $<18$ & Low & 91 \\
& $18-36$ & Medium & - \\
& $>36$ & High & 8 \\
\hline
\end{tabular}

(223.5 ppb) $>\mathrm{Zn}(97.1)>\mathrm{Cr}(10.1 \mathrm{ppb})>\mathrm{Cu}(3.5 \mathrm{ppb})>\mathrm{As}$ (3.1 ppb) >Cd (0.38 ppb). Iron ( $\mathrm{Fe}$ ) was found predominant heavy metal in groundwater (Table 9). It might be due to the dumping of the iron scraps.

Arsenic (As) was in below detectable limits (bdl) for all the samples except for GW1 and GW7 which exceeded the permissible limits of WHO standards. The spatial distribution pattern of Arsenic indicated that the leachate bearing arsenic wastes was accumulated at GW7 (1.7 km) and GW1 (3 km) borewells from the dumpsite (Fig. 10). The distribution of cadmium in groundwater samples was found 


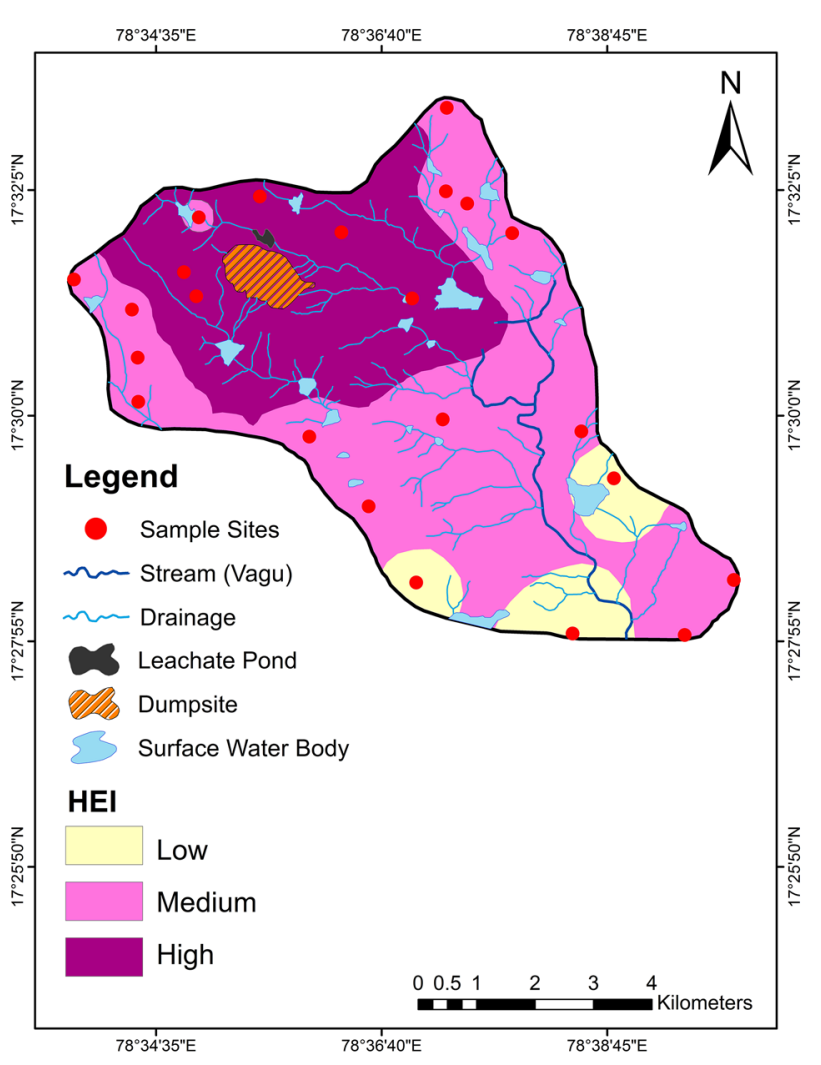

Fig. 7 Spatial distribution map of heavy metal evaluation index (HEI) groundwater

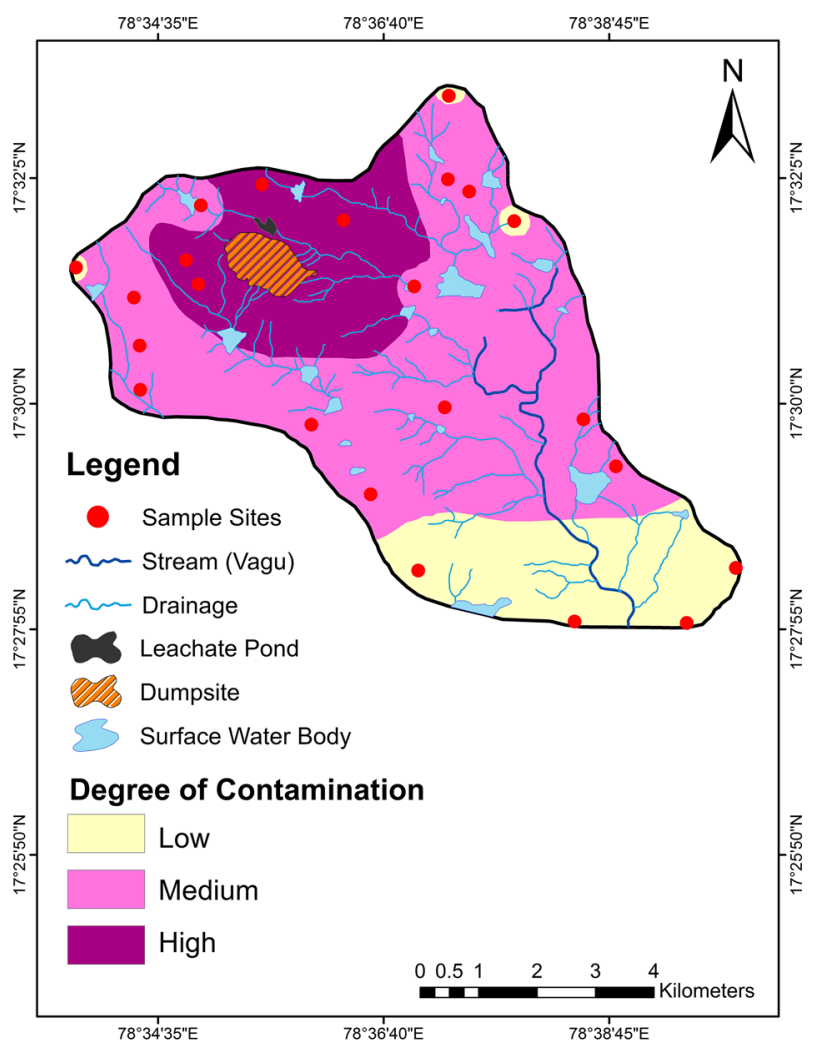

Fig. 8 Spatial distribution map of degree of contamination (Cd) in groundwater
Table 11 Correlations between heavy metal concentration and index values

\begin{tabular}{lllllllll}
\hline Variables & As & $\mathrm{Cd}$ & $\mathrm{Fe}$ & $\mathrm{Cu}$ & $\mathrm{Mn}$ & $\mathrm{Zn}$ & $\mathrm{HEl}$ & $\mathrm{Cd}$ \\
\hline $\mathrm{As}$ & 1 & 0.287 & 0.098 & 0.281 & -0.108 & 0.218 & 0.003 & -0.003 \\
$\mathrm{Cd}$ & 0.287 & 1 & -0.072 & 0.468 & -0.265 & 0.303 & -0.192 & -0.168 \\
$\mathrm{Fe}$ & 0.098 & -0.072 & 1 & 0.155 & 0.706 & 0.596 & 0.889 & 0.881 \\
$\mathrm{Cu}$ & 0.281 & 0.468 & 0.155 & 1 & -0.029 & 0.374 & 0.056 & 0.065 \\
$\mathrm{Mn}$ & -0.108 & -0.265 & 0.706 & -0.029 & 1 & -0.098 & 0.942 & 0.945 \\
$\mathrm{Zn}$ & 0.218 & 0.303 & 0.596 & 0.374 & -0.098 & 1 & 0.179 & 0.166 \\
$\mathrm{HEI}$ & 0.003 & -0.192 & 0.889 & 0.056 & 0.942 & 0.179 & 1 & 0.998 \\
$\mathrm{Cd}$ & -0.003 & -0.168 & 0.881 & 0.065 & 0.945 & 0.166 & 0.998 & 1 \\
\hline
\end{tabular}

within the permissible limits of WHO, as given in [67]. Iron (Fe) was found in below detectable limits (bdl) except for GW7 (1.7 km), GW10 (1.2 km), GW13 (1.4 km) and GW15 $(1.3 \mathrm{~km})$ showing higher concentrations due to their locations closest to the dumpsite which can be observed from the spatial distribution map of Fe in groundwater (Fig. 11). Copper (Cu) distribution in all groundwater samples was within the permissible limits of WHO, as given 


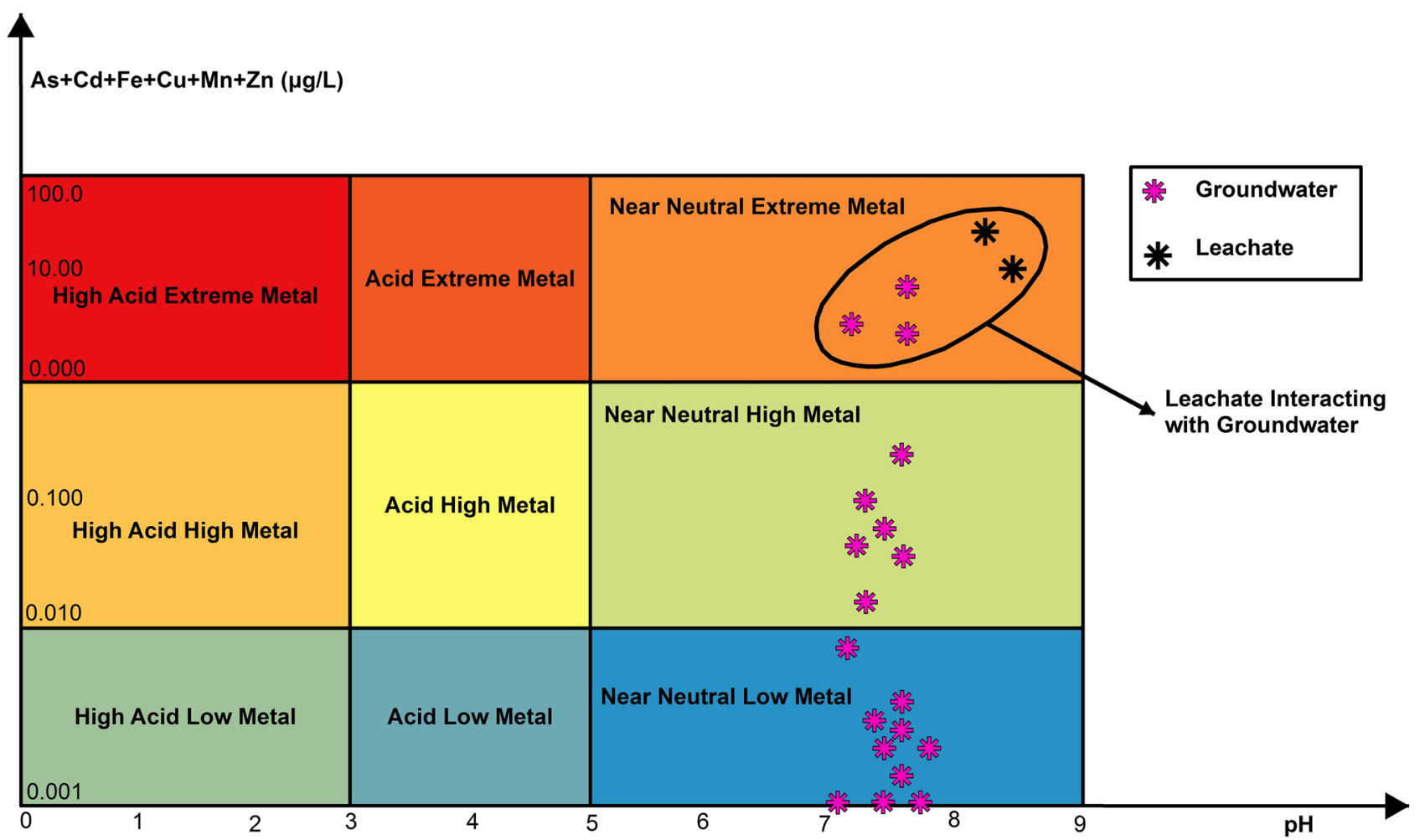

Fig. 9 Calculation of groundwater samples based on Ficklin Plot of metal load Vs pH

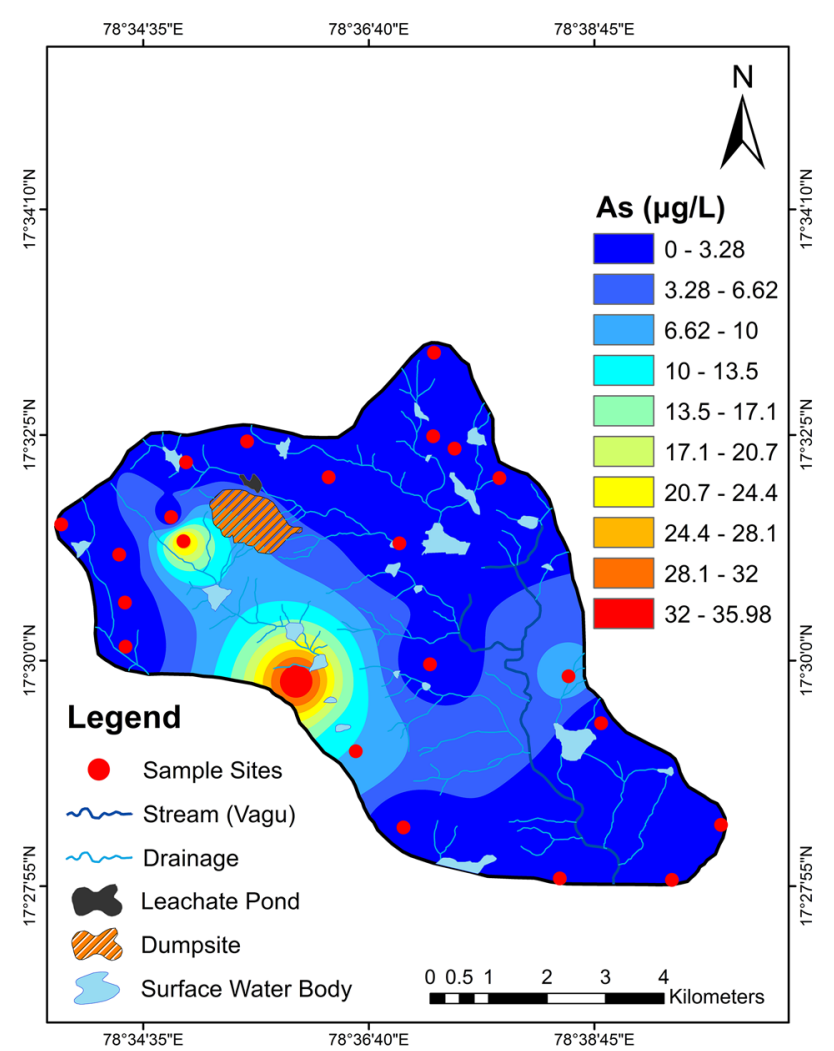

Fig. 10 Spatial distribution map of arsenic (As) in groundwater

\section{SN Applied Sciences}

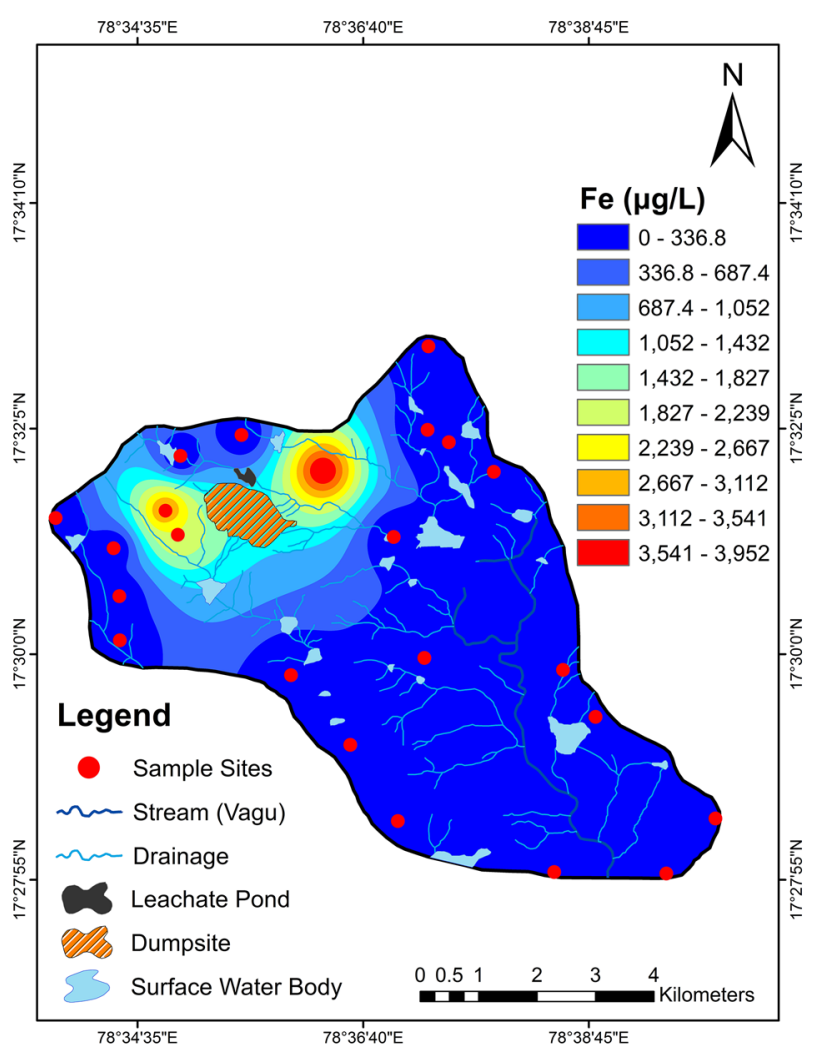

Fig. 11 Spatial distribution map of iron (Fe) in groundwater 


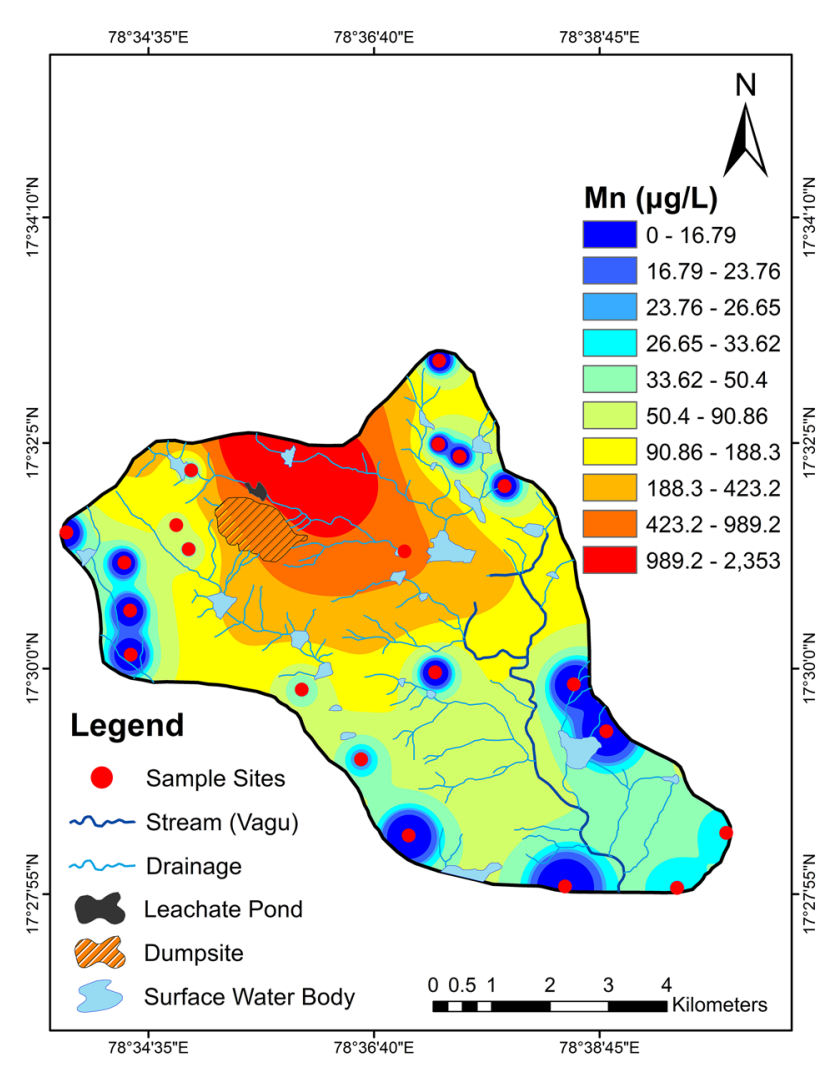

Fig. 12 Spatial distribution map of manganese $(\mathrm{Mn})$ in groundwater

in [67]. The distribution of manganese $(\mathrm{Mn})$ was found to be within the permissible limits of WHO, as given in [67]. Exceptionally, GW10 $(1.2 \mathrm{~km})$ and GW15 $(1.3 \mathrm{~km})$ wells located in the vicinity of the dumpsite showed high concentrations of manganese $(\mathrm{Mn})$ which can be observed from its spatial map (Fig. 12). It is mainly due to the leachate impact on groundwater. Nickel (Ni) was found to be within the permissible limits of WHO, as given in [67] in all the groundwater samples. However, $\mathrm{Pb}$ and $\mathrm{Ni}$ which are toxic and even in low concentrations were found to be in below detectable limits (bdl) in groundwater.

\section{Conclusion}

Groundwater is the main source of drinking and irrigation in Hyderabad City's municipal solid waste dumpsite around Jawaharnagar. The present study, therefore, focused on assessing the impact of municipal solid waste (MSW) dumpsites on seasonal and temporal variations in groundwater quality. In order to confirm groundwater quality, WHO standards were compared with major ions and heavy metal concentrations, and various graphical methods and indices were used for groundwater quality assessment that concludes: High TDS concentrations of dissolved organic and inorganic constituents were found above the permissible levels of leachate land disposal standards. Decreased biodegradability and alkaline $\mathrm{pH}$ in leachate samples indicated the old age of the dumpsite belonging to methanogenic phase. The distribution of heavy metals in groundwater was found as follows: $\mathrm{Fe}$ $>\mathrm{Mn}>\mathrm{Zn}>\mathrm{Cr}>\mathrm{Cu}>\mathrm{As}>\mathrm{Cd}$. Iron (Fe) was found to be predominantly heavy metal in groundwater. It could have been due to the dumping of iron scrap. The spatial distribution pattern of $\mathrm{HEl}$ and $\mathrm{Cd}$ of all the groundwater samples indicated that heavy metals were highly concentrated in the groundwater samples located in the vicinity than away from the dumpsite. Heavy metal pollution indices indicated that different types of wastes are being dumped without segregation process. Post-monsoon values of various parameters increased to the fact that during rainfall, leachate percolation into the surrounding environment is high due to the increased degradation of solid wastes dumped. The spatial maps of critical parameters like TDS, $\mathrm{Cl}^{-}$, and $\mathrm{NO}_{3}{ }^{-}$indicated leachate contamination in groundwater wells approx. $2 \mathrm{~km}$ from the dumpsite. WQI was computed using relative weight and quality rating scale. It shows that majority (60\%) of groundwater samples have poor water quality. This study indicates the leachates generated from the dumpsite should be properly treated prior to the land disposal to reduce the contamination. Regulatory authorities should create public awareness on solid waste management hierarchy that leads to control of the extent of groundwater pollution.

Acknowledgements The author (B. Soujanya Kamble) is extremely thankful to University Grants Commission-Rajiv Gandhi National Fellowship (UGC-RGNF) for awarding the fellowship to carry out this study and CSIR-National Geophysical Research Institute, Hyderabad for carrying out heavy metal analysis. The author conveys her gratitude to Dr. Ramana Kumar (Laboratory Incharge), Dept. of Applied Geochemistry, for immensely assisting in field and laboratory works.

\section{Compliance with ethical standards}

Conflict of interest The authors declare that they have no conflict of interest.

\section{References}

1. MoUD (2000) Manual on municipal solid waste management, the expert committee constituted by Ministry of Urban Development, Government of India

2. MoEF \& CC (2015) Municipal solid wastes (management and handling rules). Ministry of Environment, Forest and Climate Change, Government of India, New Delhi

3. Adamcova $D$, Vaverkova $M$, Barton $S$, Havlicek $Z$, Brouskova $E$ (2016) Soil contamination in landfills: a case study of landfill in 
Czech Republic. Solid Earth 7:239-247. https://doi.org/10.5194/ se-7-239-2016

4. Boateng TK, Opoku F, Akoto O (2019) Heavy metal contamination assessment of groundwater quality: a case study of Oti landfill site, Kumasi. Appl Water Sci 9:1-15. https://doi. org/10.1007/s13201-019-0915-y

5. Jhamnani B, Singh SK (2009) Ground water contamination due to Bhalaswa landfill site in New Delhi. Int J Civil Environ Eng 1:121-125

6. Kamble BS, Saxena PR (2016) Environmental impact of municipal dumpsite leachate on groundwater quality in Jawaharnagar, Rangareddy, Telangana, India. Appl Water Sci. https://doi. org/10.1007/s13201-016-0480-6

7. Kurakalva RM, Aradhib KK, Mallela KY, Venkatayogi S (2016) Assessment of groundwater quality in and around the Jawaharnagar municipal solid waste dumping site at Greater Hyderabad, Southern India. Proc Environ Sci 35:328-336. https ://doi.org/10.1016/j.proenv.2016.07.013

8. Longe EO, Balogun MR (2010) Ground water quality assessment near a municipal landfill, Lagos, Nigeria. Res J Appl Sci Eng Technol 2:39-44

9. Przydatek G, Kanownik W (2019) Impact of small municipal solid waste landfill on groundwater quality. Environ Monit Assess 191:169. https://doi.org/10.1007/s10661-019-7279-5

10. Mishra S, Tiwari D, Ohri A, Agnihotri AK (2018) Assessment of groundwater quality using WQI and GIS near the Karsara municipal landfill site, Varanasi, India. Arab J Geosci 11:252. https://doi. org/10.1007/s12517-018-3604-5

11. Sabahi EA, Abdul Rahim, Wan Zuhairi WY, Al Nozaily Fadhl, Fares Alshaebi (2009) The characteristics of leachate and ground water pollution at municipal waste solid landfill of Ibb city, Yemen. Am J Environ Sci 5:256-266. https://doi.org/10.3844/ ajessp.2009.256.266

12. Alslaibi TM, Mogheir YK, Afifi S (2011) Assessment of groundwater quality due to municipal solid waste landfills leachate. J Environ Sci Technol 4:419-436. https://doi.org/10.3923/ jest.2011.419.436

13. Vasanthi $P$, Kaliappan $S$, Srinivasaraghavan $R$ (2008) Impact of poor solid waste management on ground water. Environ Monit Assess 143:227-238. https://doi.org/10.1007/s1066 1-007-9971-0

14. Aravindan S, Shankar K (2011) Trace element concentration mapping in groundwater of Paravanar River Sub-Basin, Cuddalore District, Tamilnadu using Geospatial Technique. J Appl Geochem: 54-67

15. Aravindan S, Shankar K (2011) Ground water quality maps of Paravanar river sub basin, Cuddalore District, Tamil Nadu, India. J Indian Soc Remote Sens 39(4):565. https://doi.org/10.1007/ s12524-011-0152-9

16. Aravindan S, Shankar K (2011) Groundwater quality in Paravanar river sub-basin, Cuddalore District, Tamilnadu, India, Gondwana. Geol Mag 26(2):139-146

17. Aravindan S, Shankar K, Mini SS (2011) Integrated geohydrological studies in the sedimentary part of Gadilam river basin, Cuddalore District, Tamil Nadu. Asian J Earth Sci 4:183-192. https:// doi.org/10.3923/ajes.2011.183.192

18. Kavitha MT, Divahar R, Meenambal T, Shankar K, VijaySingh R, Haile Tamirat Dessalegn, Gadafa Chimdi (2019) Dataset on the assessment of water quality of surface water in Kalingarayan Canal for heavy metal pollution, Tamil Nadu. Data Brief 22:878884. https://doi.org/10.1016/j.dib.2019.01.010

19. Kavitha MT, Shankar K, Divahar R, Meenambal T, Saravanan R (2019) Impact of industrial wastewater disposal on surface water bodies in Kalingarayan canal, Erode district, Tamil Nadu, India. Arch Agric Environ Sci 4(4):379-387. https://doi.org/10.26832 /24566632.2019.040403
20. Kawo NS, Shankar K (2018) Groundwater quality assessment using water quality index and GIS technique in Modjo River Basin, Central Ethiopia. J Afr Earth Sci 147:300-311. https://doi. org/10.1016/j.jafrearsci.2018.06.034

21. Kumar PS, Balamurugan P (2018) Evaluation of groundwater quality for irrigation purpose in Attur Taluk, Salem, Tamilnadu, India. Water Energy Int 61(4):59-64

22. Li P, Wu J, Qian H, Zhang Y, Yang N, Jing L, Yu P (2016) Hydrogeochemical characterization of groundwater in and around a wastewater irrigated forest in the southeastern edge of the Tengger Desert, Northwest China. Expo Health 8(3):331-348. https://doi.org/10.1007/s12403-016-0193-y

23. Mahlknecht J, Merchán D, Rosner M, Meixner A, Ledesma-Ruiz $R$ (2017) Assessing seawater intrusion in an arid coastal aquifer under high anthropogenic influence using major constituents, $\mathrm{Sr}$ and B isotopes in groundwater. Sci Total Environ 587:282-295. https://doi.org/10.1016/j.scitotenv.2017.02.137

24. Shankar K, Aravindan S, Rajendran S (2010) GIS based groundwater quality mapping in Paravanar River Sub-Basin, Tamil Nadu, India. Int J Geomat Geosci 1(3):282-296

25. Shankar K, Aravindan S, Rajendran S (2011) Spatial distribution of groundwater quality in Paravanar river sub basin, Cuddalore district, Tamil Nadu. Int J Geomat Geosci 1(4):914-931

26. Shankar K, Aravindan S, Rajendran S (2011) Hydrochemical profile for assessing the groundwater quality of Paravanar river subbasin, Cuddalore district, Tamil Nadu, India. Curr World Environ 6(1):45-52. https://doi.org/10.12944/CWE.6.1.05

27. Shankar K, Aravindan S, Rajendran S (2011) Hydrogeochemistry of the Paravanar river sub-basin, Cuddalore District, Tamilnadu, India. E-J Chem 8(2):835-845. https://doi. org/10.1155/2011/107261

28. Shankar K, Aravindan S, Rajendran S (2011) Assessment of ground water quality in Paravanar river sub-basin, Cuddalore district, Tamil Nadu, India. Adv Appl Sci Res 2(5):92-103

29. Subramani T, Elango L, Damodarasamy SR (2005) Groundwater quality and its suitability for drinking and agricultural use in Chithar river basin, Tamil Nadu, India. Environ Geol 47:1099-1110. https://doi.org/10.1007/s00254-005-1243-0

30. Venkateswaran S, Karuppannan S, Shankar K (2012) Groundwater Quality in Pambar sub-basin, Tamil Nadu, India using GIS. Int J Recent Sci Res 3(10):782-787

31. Wu J, Wang L, Wang S, Tian R, Xue C, Feng W, Li Y (2017) Spatiotemporal variation of groundwater quality in an arid area experiencing long-term paper wastewater irrigation, northwest China. Environ Earth Sci 76(13):460. https://doi.org/10.1007/ s12665-017-6787-2

32. Brown RM, Mc Clelland NI, Deininger RA, Tozer RG (1970) A water quality index: do we dare? Water Sew Works 117:339-343

33. SDD, Scottish Development Department (1975) Towards cleaner water. HMSO, Report of a River Pollution Survey of Scotland, Edinburgh

34. Rabeiy RE (2017) Assessment and modeling of groundwater quality using WQI and GIS in Upper Egypt area. Environ Sci Pollut Res. https://doi.org/10.1007/s11356-017-8617-1

35. Babiker IS, Mohamed MAA, Hiyama T (2006) Assessing groundwater quality using GIS. Water Resour Manag 214:699-715. https ://doi.org/10.1007/s11269-006-9059-6

36. Boateng TK, Opoku F, Acquaah SO, Akoto O (2016) Groundwater quality assessment using statistical approach and water quality index in Ejisu-Juaben Municipality, Ghana. Environ Earth Sci 75:489. https://doi.org/10.1007/s12665-015-5105-0

37. Gebrehiwot AB, Tadesse N, Jigar E (2011) Application of water quality index to assess suitability of groundwater quality for drinking purposes in Hantebet watershed, Tigray, Northern Ethiopia. ISABB J Food Agric Sci 1:22-30 
38. Jhariya DC, Kumar T, Dewangan R, Pal Dharm, Dewangan PK (2017) Assessment of groundwater quality index for drinking purpose in the Durg district, Chhattisgarh using geographical information system (GIS) and multi-criteria decision analysis (MCDA) techniques. J Geol Soc India 89:453. https://doi. org/10.1007/s12594-017-0628-5

39. Kalaivanan K, Gurugnanam B, Pourghasemi HR, Suresh M, Kumaravel S (2017) Spatial assessment of groundwater quality using water quality index and hydrochemical indices in the Kodavanar sub-basin. Sustain Water Resour Manag, Tamil Nadu. https://doi.org/10.1007/s40899-017-0148-x

40. Lad S, Mukherjee S, Umrikar B (2019) Suitability of groundwater for drinking purposes by physico-chemical parameters and water quality index from Haveli region India. Hydrosp Anal 2(2):83-90. https://doi.org/10.21523/gcj3.18020201

41. Priya R, Elango L (2018) Evaluation of geogenic and anthropogenic impacts on spatio-temporal variation in quality of surface water and groundwater along Cauvery River, India. Environ Earth Sci 77:2. https://doi.org/10.1007/s12665-017-7176-6

42. Selvam S, Manimaran G, Sivasubramanian P, Balasubramanian N, Seshunarayana T (2013) GIS-based evaluation of water quality index of groundwater resources around Tuticorin coastal city, south India. Environ Earth Sci 716:2847-2867. https://doi. org/10.1007/s12665-013-2662-y

43. Shankar K, Kawo NS (2019) Groundwater quality assessment using geospatial techniques and WQI in North East of Adama Town, Oromia region, Ethiopia. Hydrosp Anal 3(1):22-36. https ://doi.org/10.21523/gcj3.19030103

44. Singh P, Khan I (2011) Ground water quality assessment of Dhankawadi ward of Pune by using GIS. Int J Geomat Geosci 2:688-703

45. Wagh VM, Mukate SV, Panaskar DB, Muley AA, Sahu UL (2019) Study of groundwater hydrochemistry and drinking suitability through water quality index (WQI) modelling in Kadava river basin. SN Appl Sci, India. https://doi.org/10.1007/s4245 2-019-1268-8

46. Edet $A E$, Offiong $\mathrm{OE}$ (2002) Evaluation of water quality pollution indices for heavy metal contamination monitoring. A study case from Akpabuyo-Odukpani area, lower cross river basin (southeastern Nigeria). Geo J 57:295304. https://doi.org/10.1023/ b:gejo.0000007250.92458.de

47. Kumar PS, Delson PD, Babu PT (2012) Appraisal of heavy metals in groundwater in Chennai city using a HPI model. Bull Environ Contam Toxicol 89(4):793-798. https://doi.org/10.1007/s0012 8-012-0794-5

48. Koda E, Miszkowska A, Sieczka A, Osinski P (2018) Heavy metals contamination within restored landfill site. J Environ Geotech. https://doi.org/10.1680/jenge.18.00031

49. Pawar NJ, Pawar JB (2016) Intra-annual variability in the heavy metal geochemistry of ground waters from the Deccan basaltic aquifers of India. Environ Earth Sci 75(8):654. https://doi. org/10.1007/s12665-016-5450-7

50. Prasanna MV, Praveena SM, Chidambaram S, Nagarajan R, Elayaraja $A$ (2012) Evaluation of water quality pollution indices for heavy metal concentration monitoring: a case study from Curtin Lake, Miri City, East Malaysia. Environ Earth Sci 67:1987. https:// doi.org/10.1007/s12665-012-1639-6

51. Herojeet Rajkumar, Madhuri S, Rishi Kishore Naval (2015) Integrated Approach of heavy metal pollution indices and complexity quantification using chemometric models in the Sirsa basin, Nalagarh valley, Himachal Pradesh, India. Chin J Geochem 34(4):620-633. https://doi.org/10.1007/s11631-015-0075-1

52. Selvam S, Venkatramanan S, Singaraja C (2015) A GIS-based assessment of water quality pollution indices for heavy metal contamination in Tuticorin Corporation, Tamilnadu, India. Arab
J Geosci 8(12):10611-10623. https://doi.org/10.1007/s1251 7-015-1968-3

53. Singaraja C, Chidambaram S, Srinivasamoorthy K, Anandhan P, Selvam S (2015) A study on assessment of credible sources of heavy metal pollution vulnerability in groundwater of Thoothukudi districts, Tamilnadu, India. Water Qual Expo Health. https://doi.org/10.1007/s12403-015-0162-x

54. Singh R, Venkatesh AS, Syed TH, Reddy AGS, Kumar M, Kurakalva RM (2017) Assessment of potentially toxic trace elements contamination in groundwater resources of the coal mining area of the Korba Coalfield, Central India. Environ Earth Sci 76(16):566. https://doi.org/10.1007/s12665-017-6899-8

55. Tiwari AK, Singh PK, Mahato MK (2014) GIS-based evaluation of water quality index of groundwater resources in West Bokaro Coalfield, India. Curr World Environ 9(3):843-850. https://doi. org/10.12944/CWE.9.3.35

56. Tiwari AK, De Maio M, Singh PK, Mahato MK (2015) Evaluation of surface water quality by using GIS and a heavy metal pollution index (HPI) model in a coal mining area, India. Bull Environ Contam Toxicol 95:304-310. https://doi.org/10.1007/s0012 8-015-1558-9

57. Tiwari AK, Singh PK, Singh AK, De Maio M (2016) Estimation of heavy metal contamination in groundwater and development of a heavy metal pollution index by using GIS technique. Bull Environ Contam Toxicol 96:508-515. https://doi.org/10.1007/ s00128-016-1750-6

58. Varghese J, Jaya DS (2014) Metal pollution of groundwater in the vicinity of Valiathura sewage farm in Kerala, South India. Bull Environ Contam Toxicol 93(6):694-698. https://doi.org/10.1007/ s00128-014-1410-7

59. Venkatramanan S, Chung SY, Kim TH, Prasanna MV, Hamm SY (2015) Assessment and distribution of metals contamination in groundwater: a case study of Busan City, Korea. Water Qual Expo Health 7:219-225. https://doi.org/10.1007/s12403-014-0142-6

60. Vetrimurugan E, Brindha K, Elango L, Ndwandwe OM (2016) Human exposure risk to heavy metals through groundwater used for drinking in an intensively irrigated river delta. Appl Water Sci 6:1-14. https://doi.org/10.1007/s13201-016-0472-6

61. Wagh VM, Panaskar DB, Mukate SV, Gaikwad SK, Muley AA, Varade AM (2018) Health risk assessment of heavy metal contamination in groundwater of Kadava River Basin, Nashik, India. Model Earth Syst Environ 4(3):969-980. https://doi.org/10.1007/ s40808-018-0496-z

62. Yankey RK, Fianko JR, Osae $S$, Ahialey EK, Duncan AE, Essuman DK, Bentum JK (2013) Evaluation of heavy metal pollution index of groundwater in the Tarkwa minning area, Ghana. Elixir Pollut 54:12663-12667

63. Raj GG, Joseph P, Harsha BLS, Ravi VK, Sarath CY (2015) Solid Waste management scenario in India, Issues in MSW and case study of Jawaharnagar, Hyderabad and Bengaluru Planning Colloquium. http://www.slideshare.net/kamsaniravivarma/msw-inindia. Accessed 19 Jan 2015

64. APHA (1998) American public health association, standard method for examination of water and waste water, 17th edn. APHA, Washington, DC

65. BIS (1988) Drinking water specification. Bureau of Indian Standards, New Delhi, p 10500

66. Backman B, Bodis D, Lahemo P, Rapant S, Tarvainen (1997) Application of groundwater contamination index in Finland and Slovakia. Environ Geol 36(1-2):55-64. https://doi.org/10.1007/ s002540050320

67. Qiao S, Tian T, Qi B, Zhou J (2015) Methanogenesis from wastewater stimulated by addition of elemental manganese. Sci Rep 5:12732. https://doi.org/10.1038/srep12732

68. Peter K, Morton AB, Alix PR, Anders B, Ledin A, Thomas HC (2002) Present and long-term composition of MSW landfill leachate: $a$ 
review. Crit Rev Environ Sci Technol 32(4):297-336. https://doi. org/10.1080/10643380290813462

69. WHO (2011) Guidelines for drinking water quality, 4th edn. WHO, Geneva, $\mathrm{p} 27$

70. Ganiyu SA, Badmus BS, Olurin OT, Ojekunle ZO (2018) Evaluation of seasonal variation of water quality using multivariate statistical analysis and irrigation parameter indices in Ajakanga area, Ibadan, Niger. Appl Water Sci 8:35. https://doi.org/10.1007/ s13201-018-0677-y

71. Phaniendra A, Jestadi DB, Periyasamy $L$ (2015) Free radicals: properties, sources, targets, and their implication in various diseases. Indian J Clin Biochem 30:11-26. https://doi.org/10.1007/ s12291-014-0446-0

72. Jalali M (2005) Nitrate leaching from agricultural land in Hamadan western Iran. Agric Ecosyst Environ 110:210-218. https:// doi.org/10.1016/j.agee.2005.04.011

73. Aravindan S, Shankar K, Ganesh BP, Rajan KD (2010) Hydrogeochemical mapping of in the hard rock area of Gadilam River basin, using GIS technique, Tamil Nadu. Indian J Appl Geochem 12(2):209-216

74. Aziz HA, Yussff MS, Adlan MN, Adnan NH, Alias S (2004) Physicochemical removal of iron from semi-aerobic leachate by limestone filter. Waste Manag 24:353-358. https://doi.org/10.1016/j. wasman.2003.10.006

75. Caboi R, Cidu R, Fanfani L, Lattanzi P, Zuddas P (1999) Environmental mineralogy and geochemistry of the $\mathrm{Pb}-\mathrm{Zn}$ abandoned Montevecchio-Ingurtosu mining district, Sardinia, Italy. Chronique de la rechérche miniére 534:21-28

76. Ficklin WH, Plumlee GS, Smith KS, McHugh JB (1992) Geochemical classi fication of mine drainage and natural drainages in mineralized areas. In: Kharaka YK, Maest AS (eds) Proceedings of the 7th water rock interaction congress, WRI-7, Park City, Utah, USA. Balkema AA, Rotterdam, pp 381-384

Publisher's Note Springer Nature remains neutral with regard to jurisdictional claims in published maps and institutional affiliations. 